\title{
STUDIES IN BLOOD VOLUME
}

\author{
I. The Blood Volume in Myxedema, with A Comparison of \\ Plasma Volume Changes in Myxedema and \\ CARDIAC EdEMA ${ }^{1,2}$ \\ BY WILLARD OWEN THOMPSON ${ }^{3}$
}

(From the Thyroid Clinic of the Massachusetts General Hospital and the Thorndike Memorial Laboratory of the Boston City Hospital)

(Received for publication April 28, 1926)

\section{INTRODUCTION AND LITERATURE}

One of the first things that patients with myxedema notice when thyroid extract is administered to them, is an increase in water intake and urinary output. The diuretic action of thyroid substance was indeed, one of the first effects of its use observed, and was demonstrated as early as 1890 by Leichtenstern (1). Since then several observations have been made which support the idea that the thyroid gland is a factor in maintaining the water balance.

Gardella (2) in 1910, and Paladino (3) in 1912, both found increased viscosity and decreased electrical conductivity of the blood serum in dogs and rabbits following thyroparathyroidectomy. A few years before this, however, Fano and Rossi (4) demonstrated that the viscosity of serum, while increased from thyroparathyroidectomy in animals, was not increased after extirpation of the parathyroids alone. Kottmann (5) and Deusch (6), several years later, and Neuschlosz (7) more recently, reported that increased viscosity of the serum occurred in patients with myxedema. From refractometric measurements, Deusch further concluded that the total protein of the serum is

1 This paper was read at the meeting of the Society for Clinical Investigation in Atlantic City, May 3, 1926.

2 This study was aided by a grant from the Proctor Fund of the Harvard Medical School for the Study of Chronic Diseases.

${ }^{3}$ Research Fellow in Medicine, Harvard Medical School and Massachusetts General Hospital. 
increased from 5.3 to 9.1 per cent. Hammett (8) has suggested that this interpretation should be accepted with reservations in view of the finding of Peterson, Jobling and Eggstein (9) of a progressive increase in the non-protein nitrogen and proteoses after thyroidectomy in animals and of Etienne, Richard and Roesch (10) of an increase of urea nitrogen in the blood in thyroid insufficiency. The increase in all three factors is, however, more marked in experimental myxedema and in cretinism than in human myxedema and Deusch's conclusion that there is high serum protein in myxedema is probably correct.

Deusch also found the sodium chloride in serum to be within normal limits in myxedema and observed little change in this respect before and after thyroid administration. From this he concluded that salt and water excretion ran parallel with their removal from the tissues and that the water content of the serum was therefore unchanged by thyroid. He concluded that the increase in protein was an absolute and not a relative one.

In 1917 Eppinger (11) made an important contribution to the subject when he demonstrated that salt solution injected subcutaneously and water given by mouth are absorbed more slowly and excreted more slowly in thyroidectomized than in normal dogs, and more slowly in normal than in thyroid-fed ones. He also observed that in some cases of cardiac and nephritic edema when all known methods of causing fluid elimination had failed, the administration of thyroid substance produced marked diuresis. More recently Danzer (12) has reported that giving thyroid substance caused a distinct tendency to rapid absorption in three cases of pleural effusion following lobar pneumonia. The difficulty with such observations is that controls cannot be obtained. Loeb (13) however substantiates this view in a reference to the fact that Hoover found a collection of a certain amount of fluid in the peritoneal cavity in guinea pigs suffering from marked inanition, while it was absent in the large majority of animals in which the same or even a greater amount of inanition was produced through the combined effects of thyroid feeding and diminished intake of food.

Recently Hammett (8) has shown that loss of the thyroid gland in male rats 100 days of age, causes a decrease in the water percentage and an increase in the refractive index of blood serum. 
An observation of some interest is that of Wilhelmj and Fleischer (14), (15) that thyroxin fed to normal guinea pigs causes an average decrease in surface tension of plasma of 3.7 dynes and that thyroidectomy in these animals causes an average increase in surface tension of plasma of 5.1 to 5.7 dynes. Thyroxin added directly to plasma had no effect.

Two years ago Hildebrandt (16) made the very important observation that the intravenous injection of $1 \mathrm{mg}$. of thyroxin in rabbits after a hunger-thirst period of 14 to 15 hours caused marked hydremia with a maximum in the fifth or sixth hour, at which time the total quantity of blood was usually raised 40 per cent above the normal (as measured by hemoglobin and red blood cell dilution). Parallel to this occurrence there was a large water and salt diuresis. The normal red count was reached again after 36 hours.

In support of the idea therefore, that the thyroid gland is concerned in water balance, there are the following observations:

1. Thyroidectomy in various animals causes:

$a$. Increased viscosity of the serum.

b. Decreased electrical conductivity of the serum.

$c$. Increased refractive index of the serum.

$d$. Decreased water per cent of serum.

2. Thyroid insufficiency in human beings causes:

a. Increased viscosity of the serum.

$b$. Increased refractive index of the serum.

3. Intravenous injection of thyroxin in normal rabbits produces:

a. Marked hydremia.

$b$. Pronounced water and salt diuresis.

Thus far no direct observations of the total quantity of circulating blood or plasma have been made in disorders of the thyroid gland. Since changes in viscosity, refractive index, electrical conductivity and water percentage of serum, and changes in hemoglobin concentration and red blood cell count may occur without changes in the total quantity of serum or plasma it is important to learn whether there is a relation between them and disease of the thyroid gland. The fact that in experiments thus far reported the results all point in the same direction certainly suggests and points to the fact that the serum and plasma are concentrated in myxedema. 
In the fall of 1923, I began to make observations on the plasma volume in myxedema. This work was mentioned by Means (17) in his address before the Association for the Study of Internal Secretions in May, 1925. Nine patients have been studied, numerous observations having been made on each one (except patient 3) while myxedematous and while receiving thyroid. The cases have consistently shown the same results and a report now seems justified.

\section{METHOD}

The plasma volume method of Keith, Rowntree and Geraghty (18) was used except that brilliant vital red, as suggested by Evans, was substituted for vital red and isotonic sodium oxalate as suggested by Hooper et al. (19), was used instead of powdered oxalate, to prevent clotting. This method is generally recognized as being accurate within 5 per cent. In general it proved to be as accurate as this in my work. Total blood volumes were calculated from hematocrit values as determined from calibrated centrifuge tubes. Hemoglobins, where reported, were done by the Newcomer method. I found great difficulty in matching colors with this hemoglobin method and only the general trend of the values is of any significance.

In all of the patients the blood was collected in the morning and its collection was preceded by a hunger-thirst period of 14 to 18 hours. In all except the first three cases it was also preceded by a rest period of at least one-half hour. In all except the first two cases withdrawal of blood was preceded by a basal metabolism determination done with a Roth-Benedict apparatus.

Only typical cases of myxedema were selected for these observations and cases of so-called related conditions supposed by some to be of thyrogenous origin were omitted. Due to the scarcity of untreated patients with myxedema, it was necessary to use patients who had been previously treated.

III. THE CONSTANCY OF THE PLASMA AND CALCULATED TOTAL BLOOD VOLUMES IN A NORMAL INDIVIDUAL

Of thirteen plasma volume observations made of a normal individual over a period of nearly three months, only two varied more than 5 per 
cent from the average (table 1). All of the calculated total blood volumes were within 7 per cent of the average. Blood for these observations was collected in the morning after a hunger thirst period of 14 to 18 hours, but was not preceded by a rest period. The results serve to illustrate that total plasma and calculated total circulating

TABLE 1

The constancy of plasma and calculated total blood volumes in a normal man Age 42 years, height $166 \mathrm{~cm}$.

\begin{tabular}{|c|c|c|c|c|c|c|c|c|}
\hline \multirow{2}{*}{ Date } & \multirow{2}{*}{ Weight } & \multirow{2}{*}{ R.B.C.* } & \multirow{2}{*}{$\mathbf{H b}$} & \multirow{2}{*}{$\underset{\text { ucrit }}{\text { Hemat- }}$} & \multicolumn{2}{|c|}{ Plasma volume } & \multicolumn{2}{|c|}{ Total blood volume } \\
\hline & & & & & Amount & $\begin{array}{c}\text { Per kilo- } \\
\text { gram }\end{array}$ & Amount & $\begin{array}{l}\text { Per kilo- } \\
\text { gram }\end{array}$ \\
\hline & kg. & millions & per cent & $\begin{array}{c}\text { per cent } \\
\text { cells }\end{array}$ & $c c$. & $c c$. & $c c$. & $c c$. \\
\hline $1 / 15 / 24$ & 61.4 & 4.8 & 98 & 54.2 & 2,585 & 42.2 & 5,650 & 92.2 \\
\hline $1 / 21 / 24$ & 60.4 & 4.5 & 99 & 58.6 & 2,080 & 34.5 & 5,030 & 83.5 \\
\hline $1 / 24 / 24$ & 61.4 & 4.9 & 92 & 49.2 & 2,555 & 41.6 & 5,030 & 82.0 \\
\hline $1 / 29 / 24$ & 62.7 & 4.3 & 85 & 47.2 & 2,775 & 44.3 & 5,270 & 84.0 \\
\hline $2 / 2 / 24$ & 63.4 & & 94 & 50.0 & 2,800 & 44.2 & 5,600 & 88.5 \\
\hline $2 / 7 / 24$ & 61.1 & 4.7 & 91 & 49.9 & 2,520 & 41.2 & 5,030 & 82.3 \\
\hline $\begin{array}{c}2 / 15 / 24 \\
\text { (12:15 p.m.) }\end{array}$ & 60.7 & 4.6 & 100 & 49.4 & 2,635 & 43.3 & 5,200 & 85.6 \\
\hline $\begin{array}{c}2 / 15 / 24 \\
(1: 30 \text { p.m. })\end{array}$ & 60.7 & 4.8 & 98 & 50.0 & 2,480 & 41.0 & 4,970 & 82.0 \\
\hline $\begin{array}{c}2 / 19 / 24 \\
(8: 40 \text { a.m.) }\end{array}$ & 60.4 & 4.1 & 95 & 48.3 & 2,865 & 47.4 & 5,550 & 92.0 \\
\hline $\begin{array}{c}2 / 27 / 24 \\
(10: 15 \text { a.m.) }\end{array}$ & 60.9 & 4.0 & 99 & 52.0 & 2,730 & 44.9 & 5,690 & 93.5 \\
\hline $\begin{array}{c}2 / 27 / 24 \\
(1: 30 \text { p.m. })\end{array}$ & 60.9 & & & 51.5 & 2,755 & 45.2 & 5,680 & 93.3 \\
\hline $3 / 23 / 24$ & 58.9 & 4.6 & 94 & 47.9 & 2,510 & 42.6 & 4,810 & 81.8 \\
\hline $4 / 6 / 24$ & 59.8 & 4.6 & 93 & 48.6 & 2,635 & 44.0 & 5,125 & 85.7 \\
\hline
\end{tabular}

* In this and the subsequent tables R.B.C. means red blood cells; $\mathrm{Hb}$, hemoglobin; B.M.R., basal metabolism rate.

blood seem to be fairly constant in the same individual under approximately the same conditions. Several similar results could be cited.

In Lamson's (20), (21), opinion the vital red method is accurate for measuring plasma volumes, but he states that total blood volumes calculated from hematocrit estimations are not true measures of the total quantity of circulating blood because these differ when made on 
blood from different parts of the body and from the same part under different conditions. He states, however, that, under basal conditions, both plasma and calculated total blood volumes are fairly constant quantities and most of my observations in myxedema were made under basal conditions. Only 3 hematocrit estimations vary more than 3 per cent from the average of the group (table 1). This is a fairly typical example. The hematocrit readings of blood drawn before dye injection and that on blood withdrawn after dye injection usually varied less than 1 per cent from each other. No claim is made to accuracy for hematocrits as here determined. They appear, however, to be accurate enough to show gross changes in the volume of circulating cells (say 10 per cent and over) under basal conditions.

\section{PLASMA VOLUME CHANGES IN MYXEDEMA}

In all of the cases of myxedema, the administration of thyroid substance produced a well marked and permanent increase in the plasma volume, a decrease in the hematocrit reading and in the red blood count. In two of the cases the hematocrit value and red count subsequently increased due to an increase in the volume and number of circulating cells probably as a result of stimulating the bone marrow on administering thyroid extract. As a group, when not taking thyroid extract the average of the plasma volumes was low- $35.4 \mathrm{cc}$. per kilogram and $1360 \mathrm{cc}$. per square meter, as compared with normal values of 42 to $52 \mathrm{cc}$. per kilogram and 1500 to $2000 \mathrm{cc}$. per square meter. The significant thing is, however, not the average change but that observed in each case because the myxedematous level in some was within the so-called normal limits. The change in these cases was, nevertheless, as great on the average as in the others. Attention is called to the fact that the increase in plasma was absolute and not merely relative due to loss of weight. Even cases 6 and 8 (tables 8 and 10), which lost weight when given thyroid extract showed total plasma increases of 14.0 and 20.9 per cent respectively. It is of interest to note that the change in total plasma volume in these two cases was less, however, than in the other patients who lost less weight. Both of these patients had slight pitting edema and marked dyspnea on exertion. The possibility of slight cardiac edema masking the myxedematous reduction in plasma volume is suggested. 


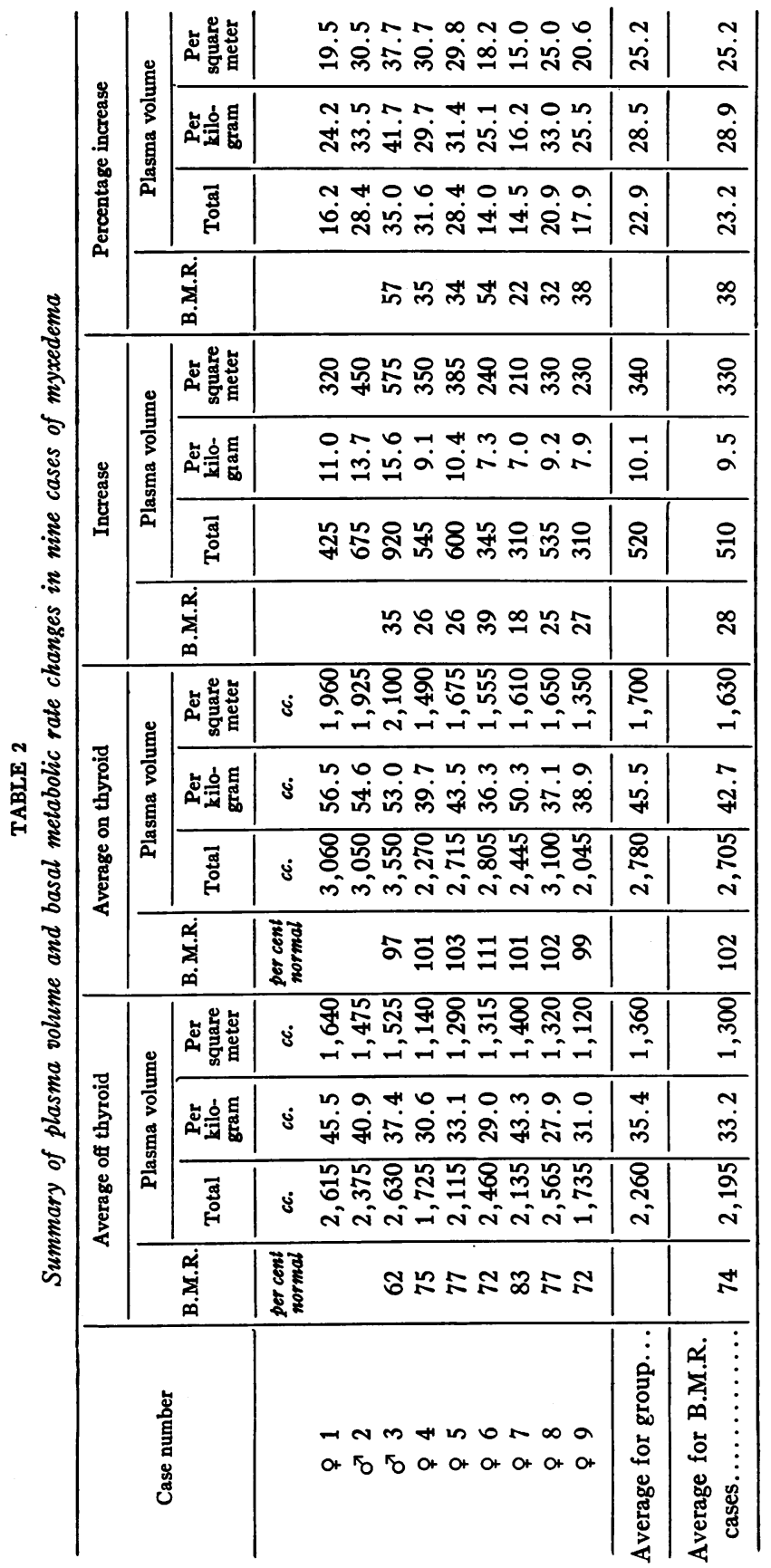




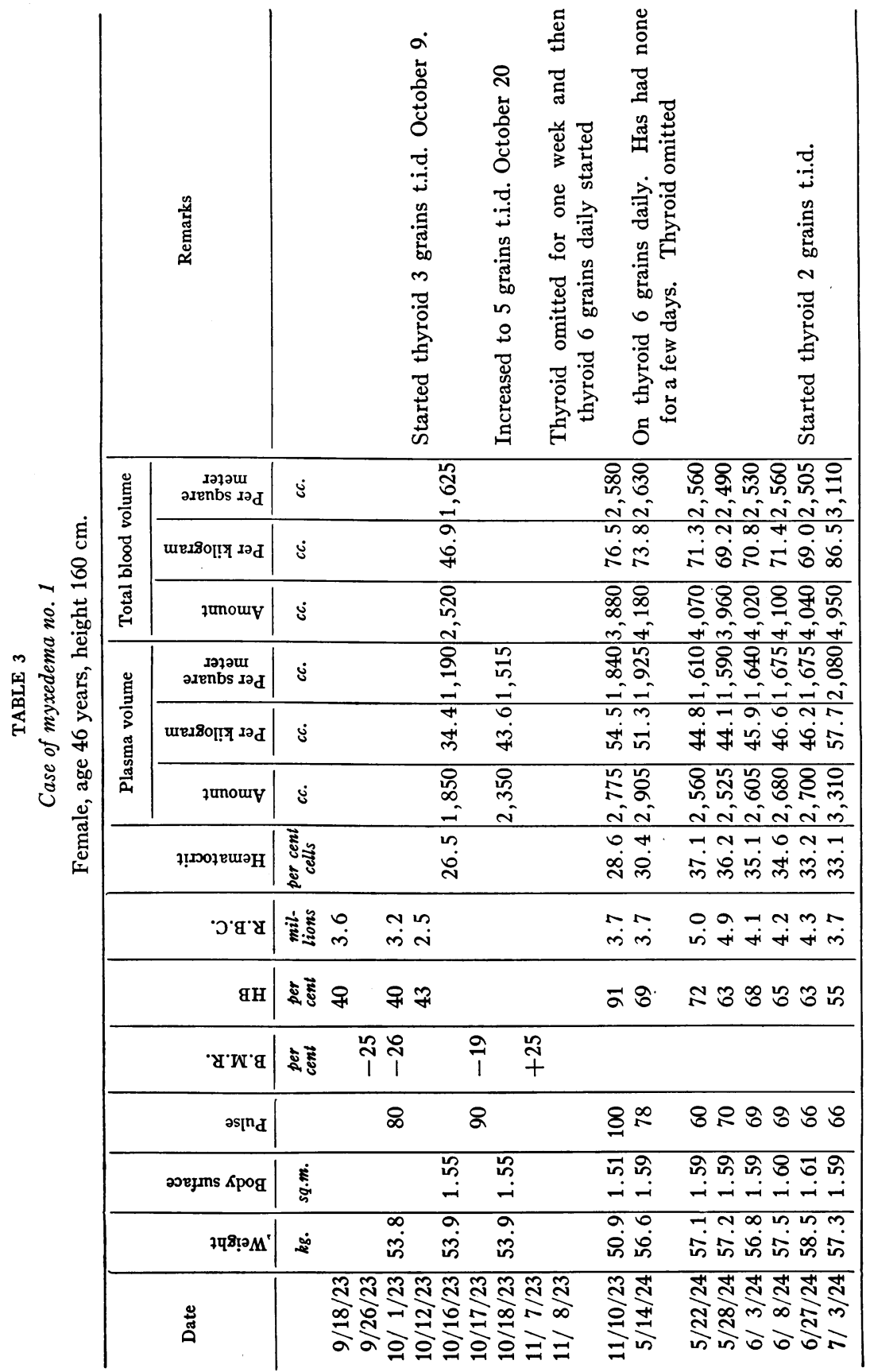




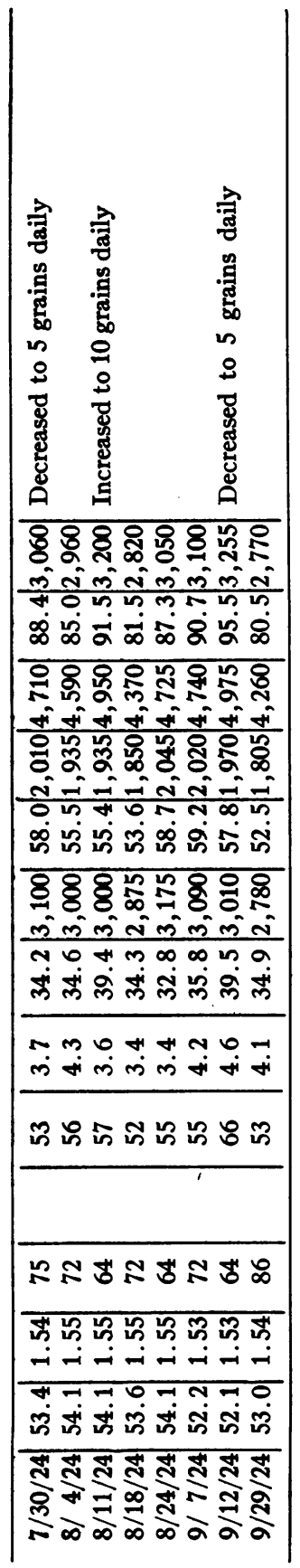




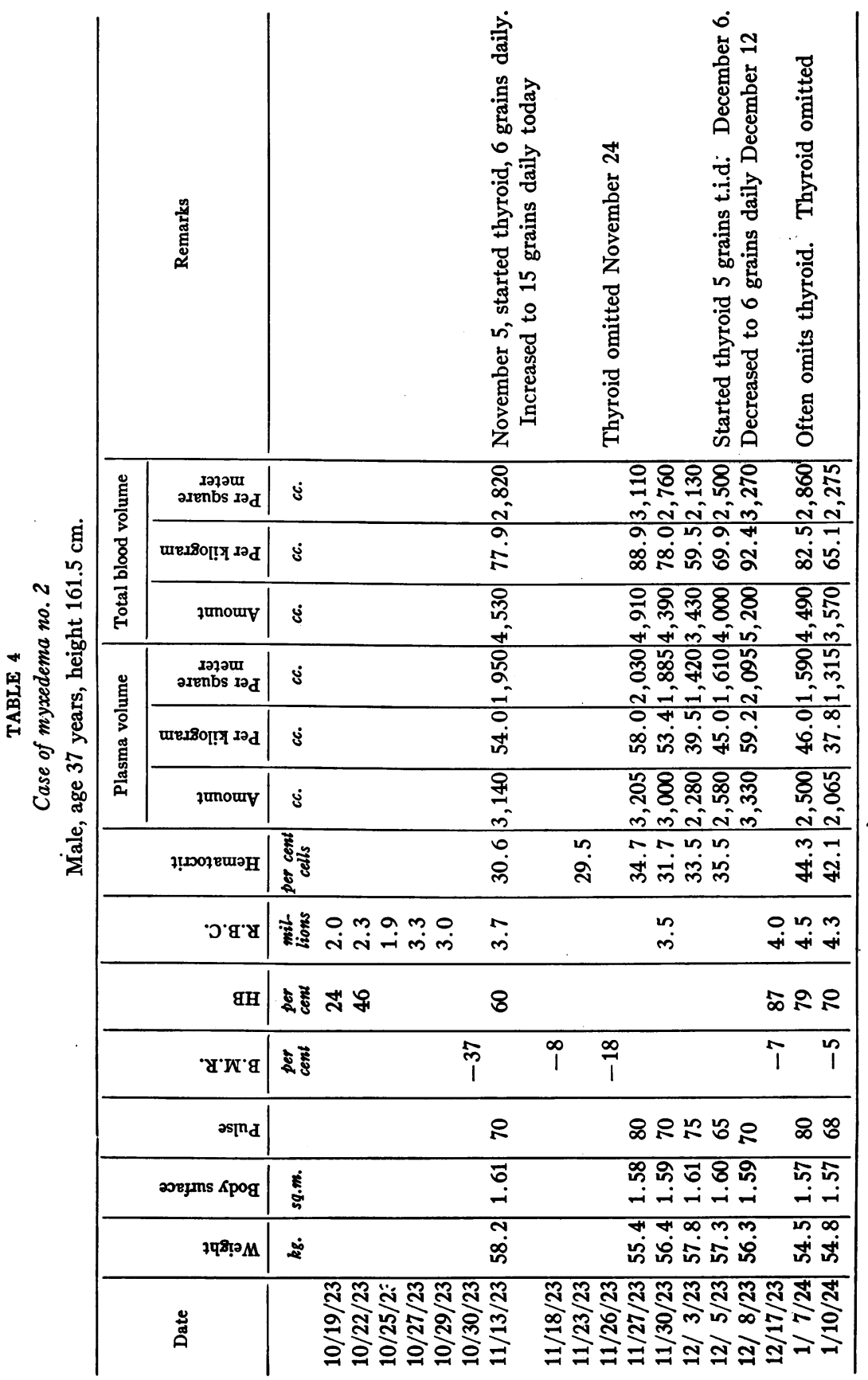




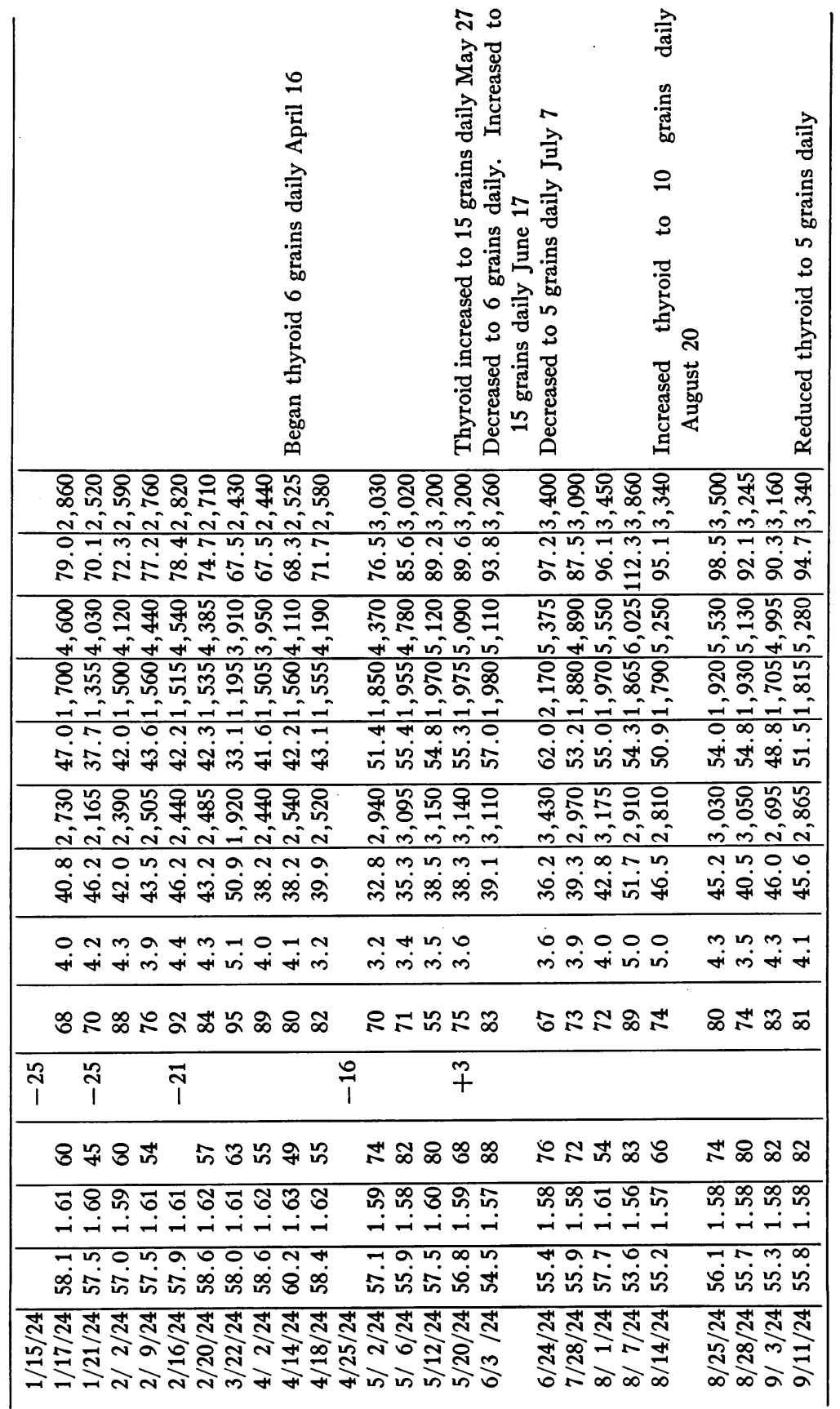




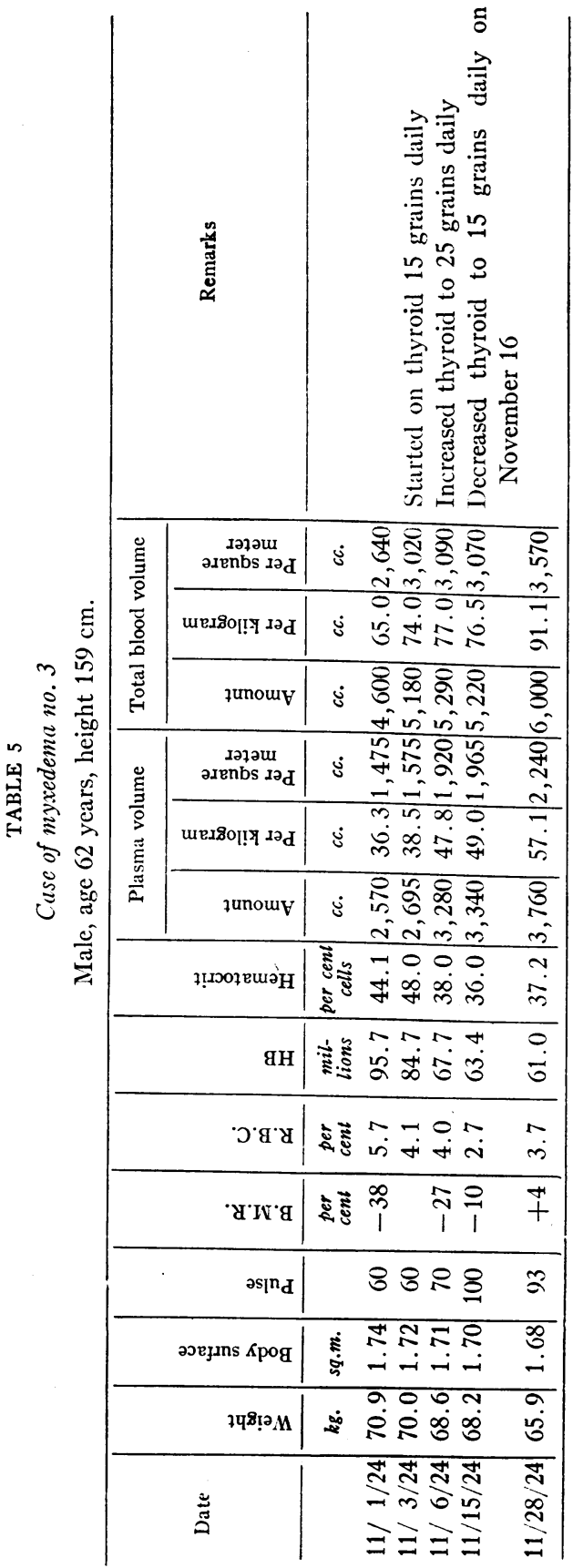




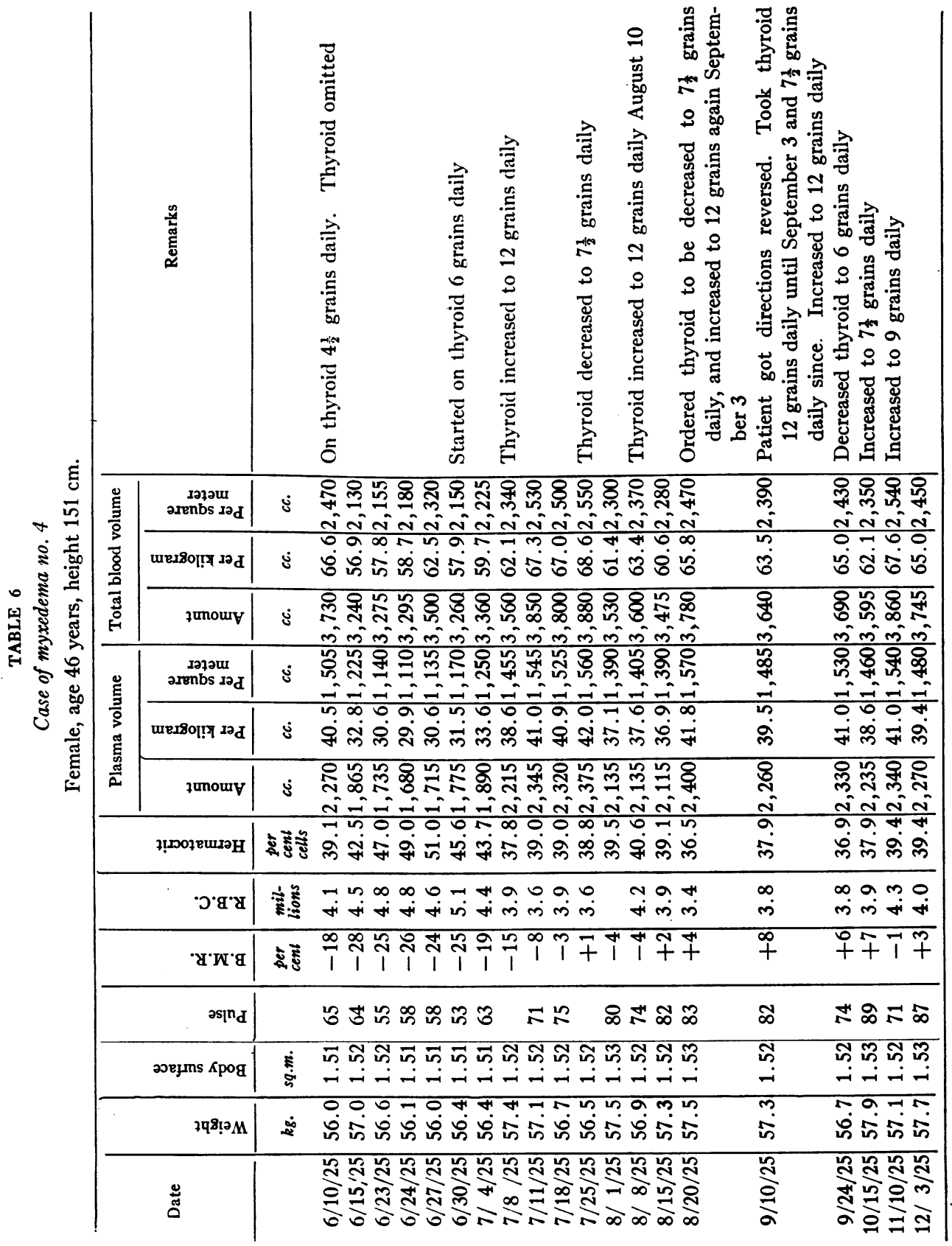




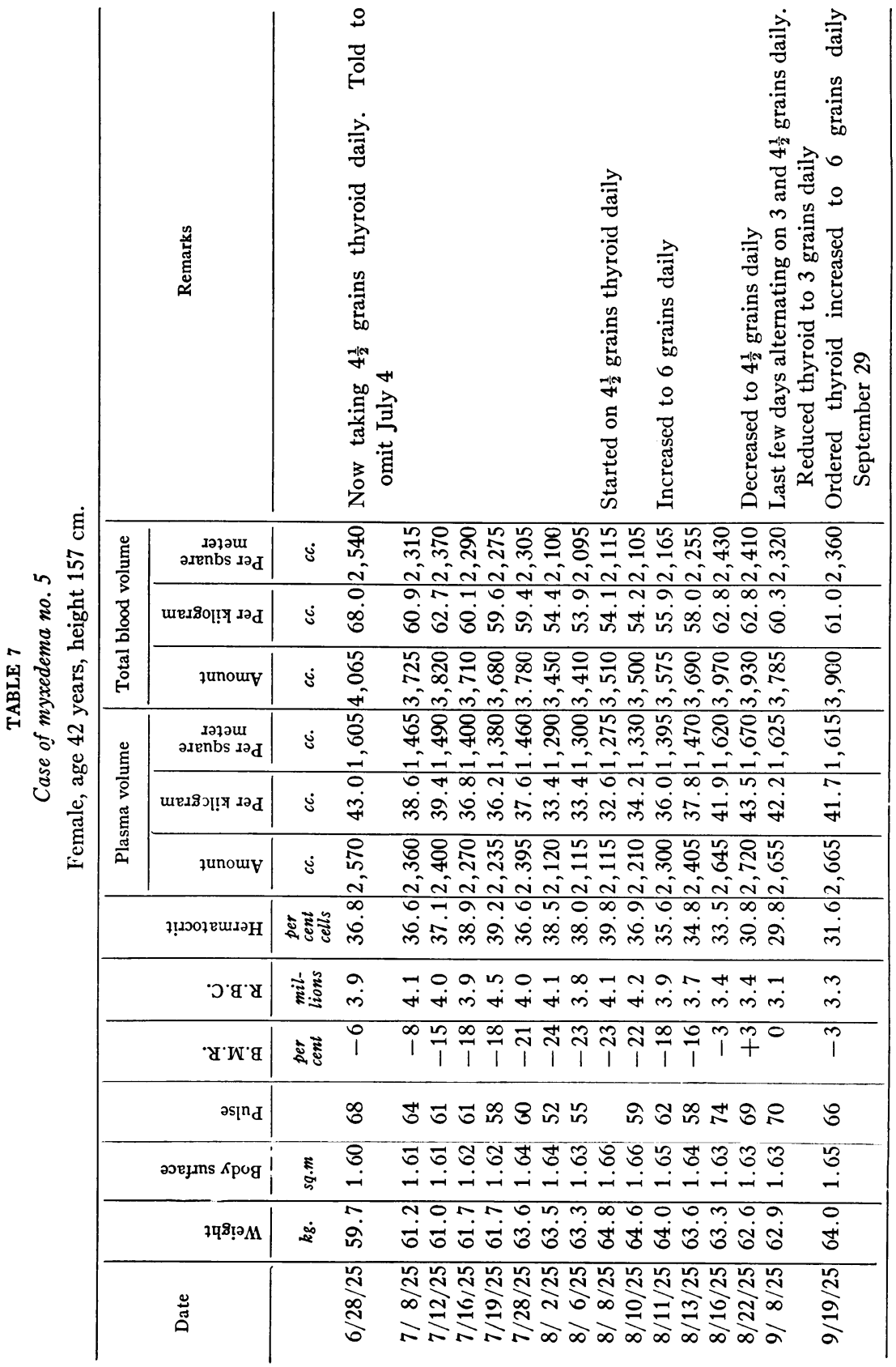




\begin{tabular}{|c|c|}
\hline 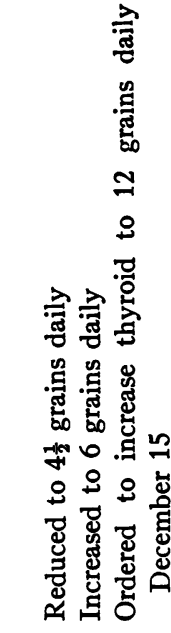 & 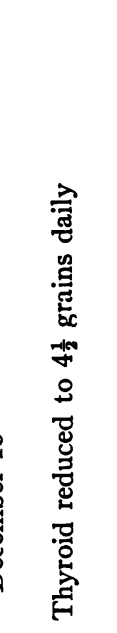 \\
\hline 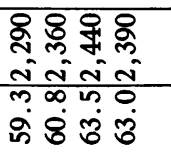 & 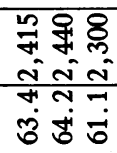 \\
\hline 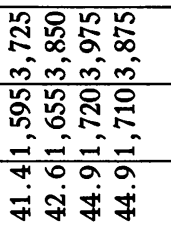 & 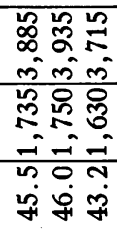 \\
\hline 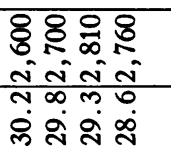 & 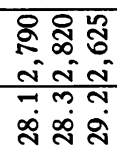 \\
\hline iि in & $\begin{array}{l}-\infty \\
\dot{H}\end{array}$ \\
\hline 자 & $\underset{7}{7} \frac{ \pm}{+}$ \\
\hline 요용 & ำำ \\
\hline 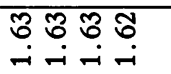 & 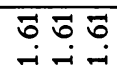 \\
\hline 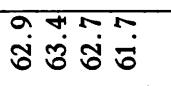 & 郯 \\
\hline 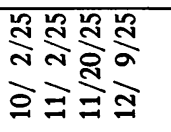 & 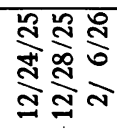 \\
\hline
\end{tabular}




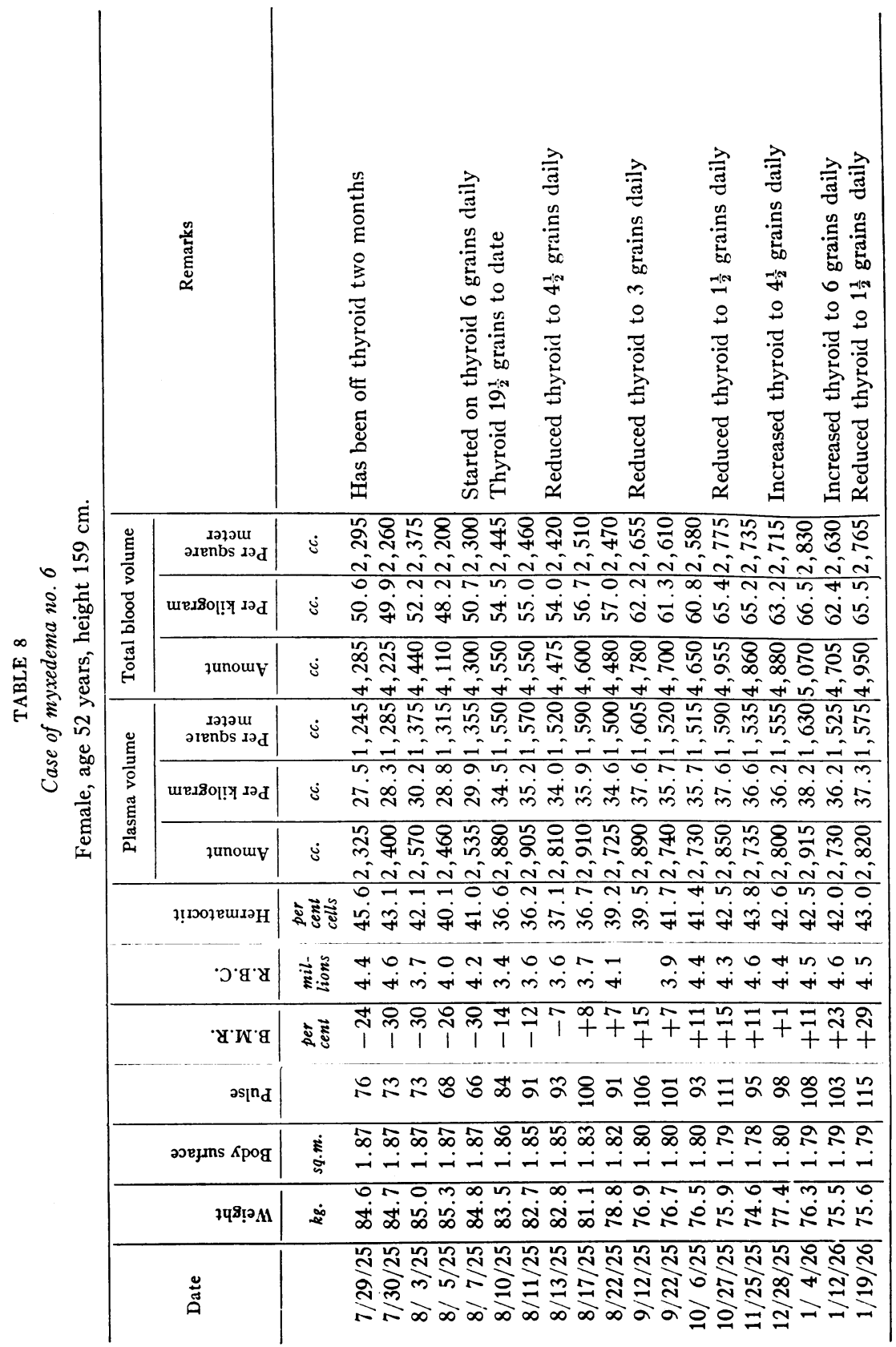




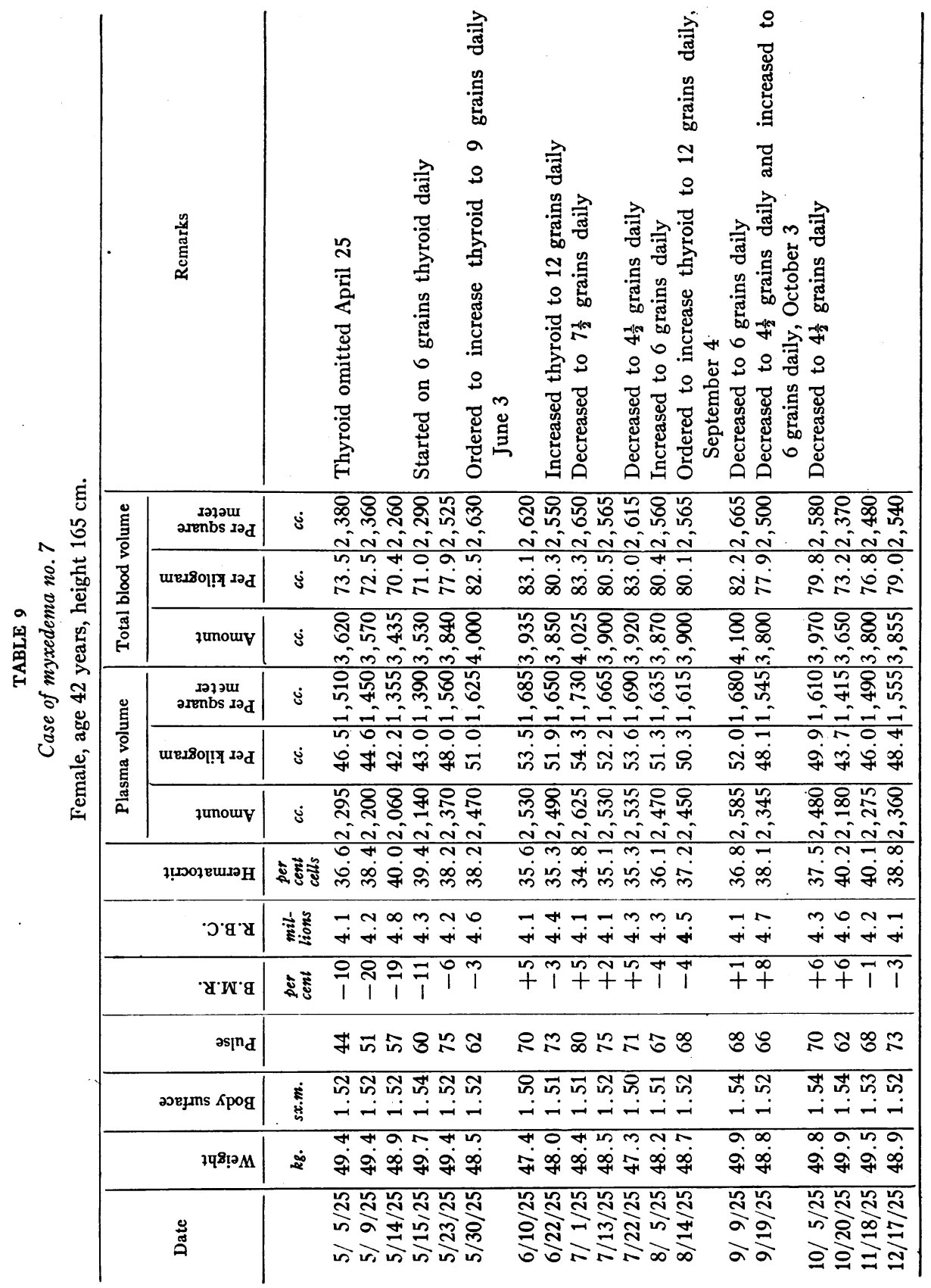




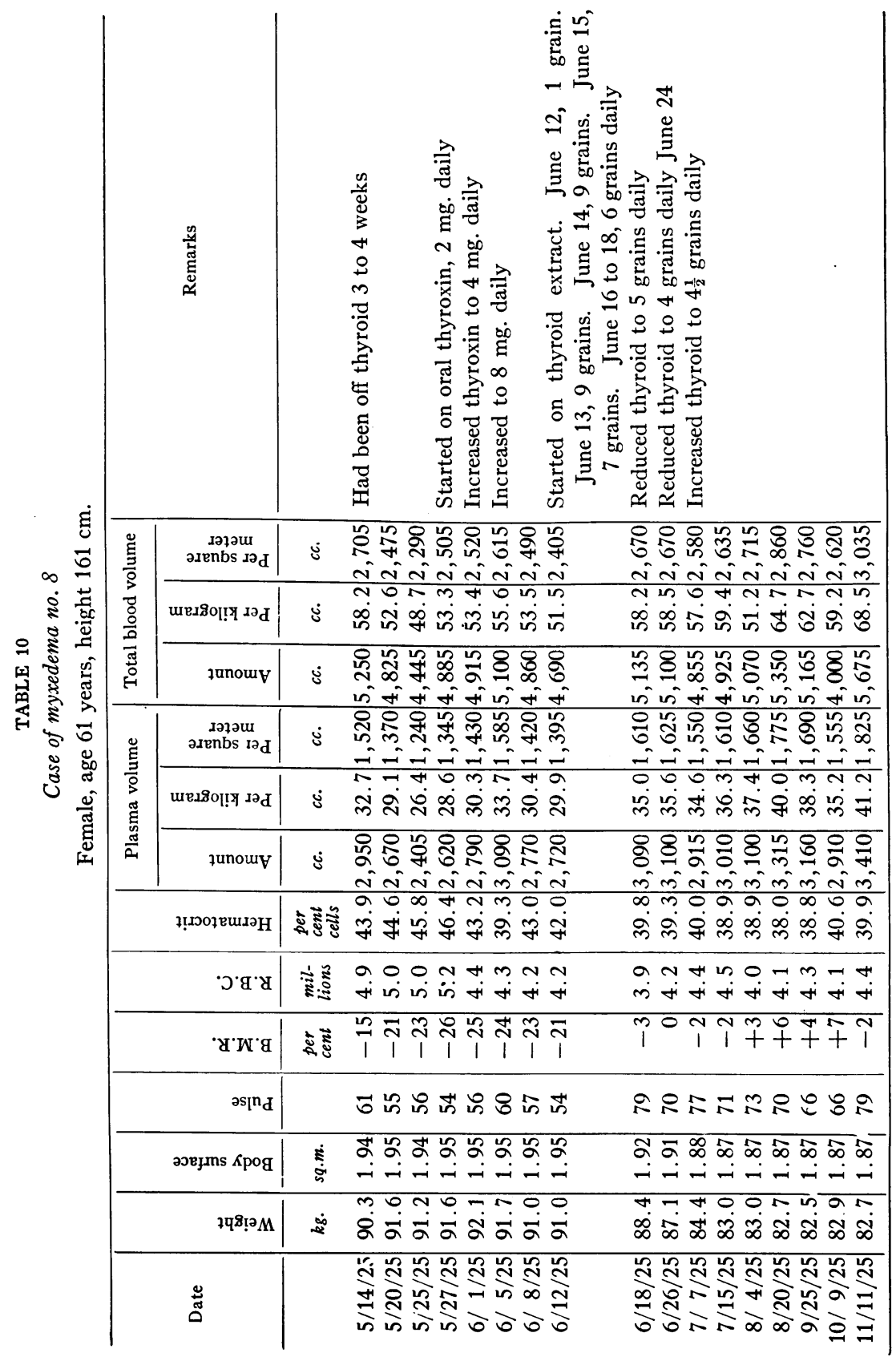




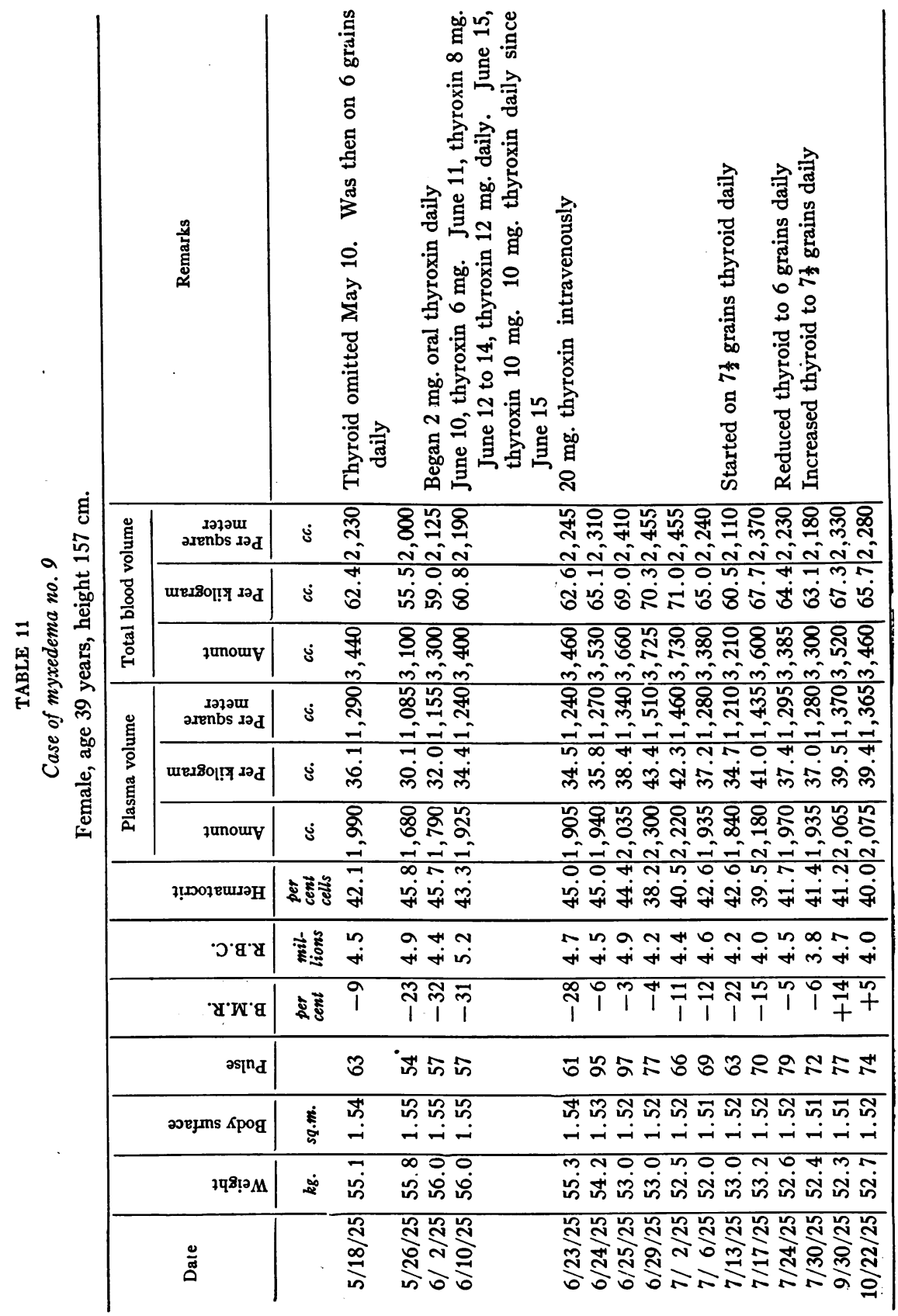


Patients may show a marked plasma volume decrease on omission of thyroid extract, with practically no change in weight. This is well illustrated by case 4 .

The percentage increase in total plasma over the myxedematous level varied from 14.0 to 35.0 per cent, that in the plasma per kilogram from 16.2 to 41.7 per cent, and that in the plasma per square meter from 17.1 to 37.7 per cent. The average increases in the three for all nine patients were $22.9,28.5$ and 25.2 per cent, respectively. With an average basal metabolism increase over the myxedematous level of 38 per cent the last seven cases showed average percentage increases in total plasma, plasma per kilogram and plasma per square meter of $23.2,28.9$ and 25.2 per cent, respectively.

I have ascertained the average plasma volume and basal metabolism figures for each patient both while off and on the administration of thyroid extract, as well as the gross and percentage increases in the two over the myxedematous level (table 2) as well as the data collected on each individual patient, the order of patients in table 2 being preserved throughout (tables 3 to 11).

To prove that the plasma volume increase endures as long as treatment is continued and is not dependent on the elimination of excess fluid by diuresis, a study was made of all of the patients in whom a control observation was made before omitting the administration of thyroid extract; in all of them it was found that a decrease was observed after the omission. Two of these patients (cases 4 and 5) had been treated for 14 and 15 months respectively, but in both the omission produced a well marked decrease in plasma volume and subsequent administration, a return to the previous level. All patients (except number 3) were followed furthermore, for several months after treatment was begun and in all the increase in plasma volume persisted.

V. TIME REQUIRED FOR PLASMA VOLUME REDUCTION TO OCCUR AFTER OMISSION OF THYROID EXTRACT

The time required for plasma volume reduction to occur after omitting the administration of thyroid extract varies considerably from individual to individual. In all of the cases a well marked change had occurred within ten days after omission. In patient number 4 
the level was as low in ten days as it was in the following ten while in patient number 5 it kept slowly dropping over a period of 5 weeks and, if giving thyroid extract had been withheld longer might have dropped further. Plummer and Boothy (22) have estimated that it takes fifty to sixty days for the effects of a single intravenous injection of thyroxin to wear off. Five of these patients were without thyroid extract for considerably shorter periods than this; it is quite possible that the changes in the plasma would have been more marked had the administration been withheld for a longer time.

Cases previously untreated might show greater changes, as case 2 illustrates. When first seen, she presented the most marked symptoms of myxedema I have ever seen. Just after she had started 9 grains of thyroid extract daily and while her metabolic rate was still low, the total plasma was $1850 \mathrm{cc}$. Her veins were small, difficult to distend and puncture, her blood was extremely viscous and clotted rapidly. The day following the first plasma volume determination, her basal metabolism was -19 per cent. Two days afterward the total plasma was $2350 \mathrm{cc}$. The fact that she took 9 grains of thyroid extract daily for several days before the first estimation of plasma volume indicates that this value may have been wrong, that is to say too low. The second estimation two days later, however, as has been said was less than that subsequently found even after the non-administration of thyroid extract for six weeks, after treatment with it for six months. Under these circumstances the first observation then apparently too low may have been approximately correct. If so, subsequent determinations represent an increase in plasma volume of at least 62 per cent over the myxedematous level.

VI. RELATION BETWEeN PLASMA VOLUME AND BASAL METABOLIC RATE

A parallelism appears to exist between plasma volume and basal metabolism (figs. 1, 2 and 3 plotted from the data in tables 6, 7 and 10).

Inasmuch as basal metabolism is a function of surface area, a comparison with plasma per square meter is justified. In interpreting such charts, it must be born in mind that there is a 5 per cent error in both plasma volume and basal metabolic rate determinations and that, therefore, only the general trend of the curves is of significance. 


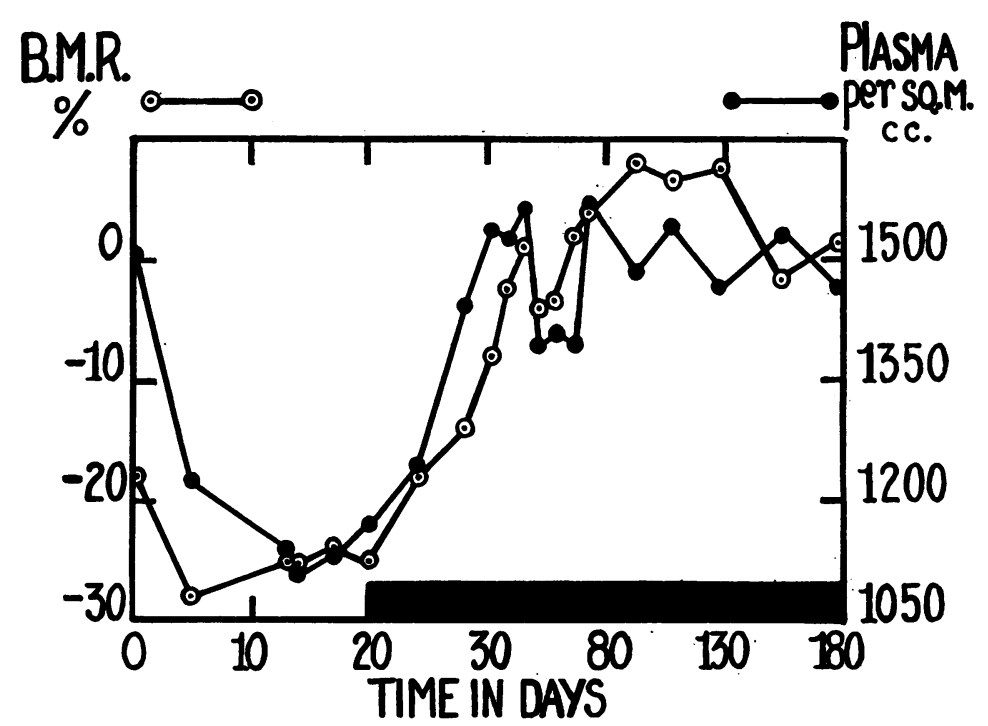

Fig. 1. Case of Myxedema No. 4

Black area in this and subsequent figures denotes the period of thyroid medication. The curves show striking parallelism between basal metabolic rate (B.M.R.) and plasma per square meter. Thyroid extract administration omitted at beginning of chart.

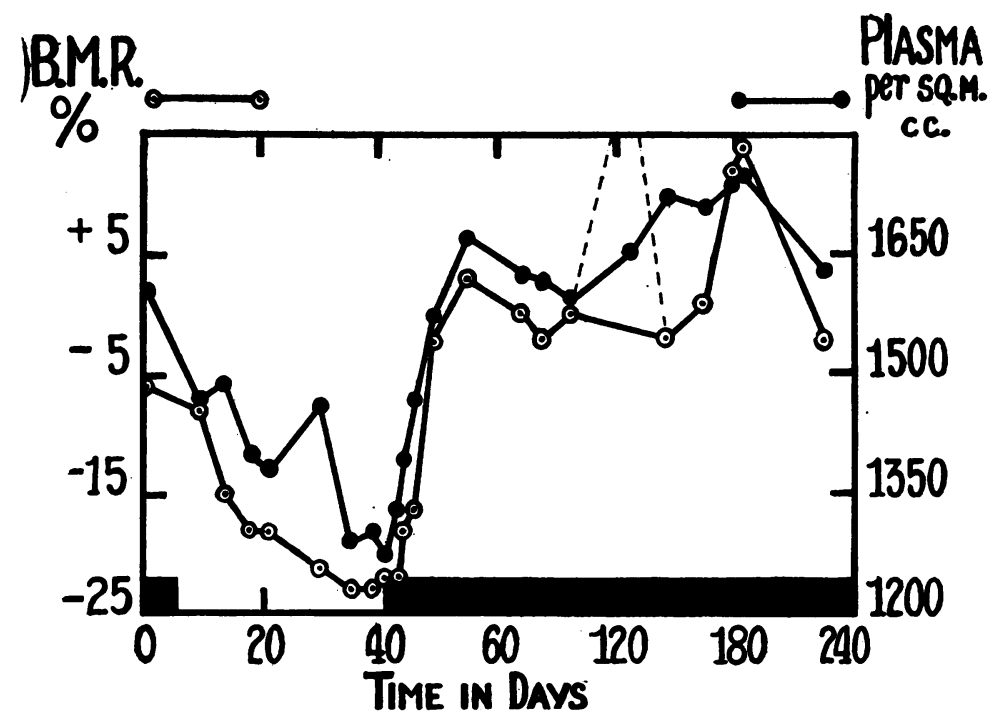

Fig. 2. Case of Myxedema No. 5

These curves also show parallelism between B.M.R. and plasma per square meter. Note the slow fall on omission of thyroid extract therapy and rapid rise on administering it. Inasmuch as several B.M.R. observations on 6 grains thyroid daily ranged from -3 per cent to +3 per cent, one observation of +22 per cent on this dose is undoubtedly high and is connected to the others by dotted lines. 
At the suggestion of Dr. Means, these data of the seven cases have been plotted (fig. 4). For each patient represented in figure 4, a point was plotted for the average without thyroid extract administration and another for the average with treatment; these points have been connected with a straight line (fig. 5).

This figure gives at first the impression of a striking parallelism between the seven lines. When inspected closely, however, it will

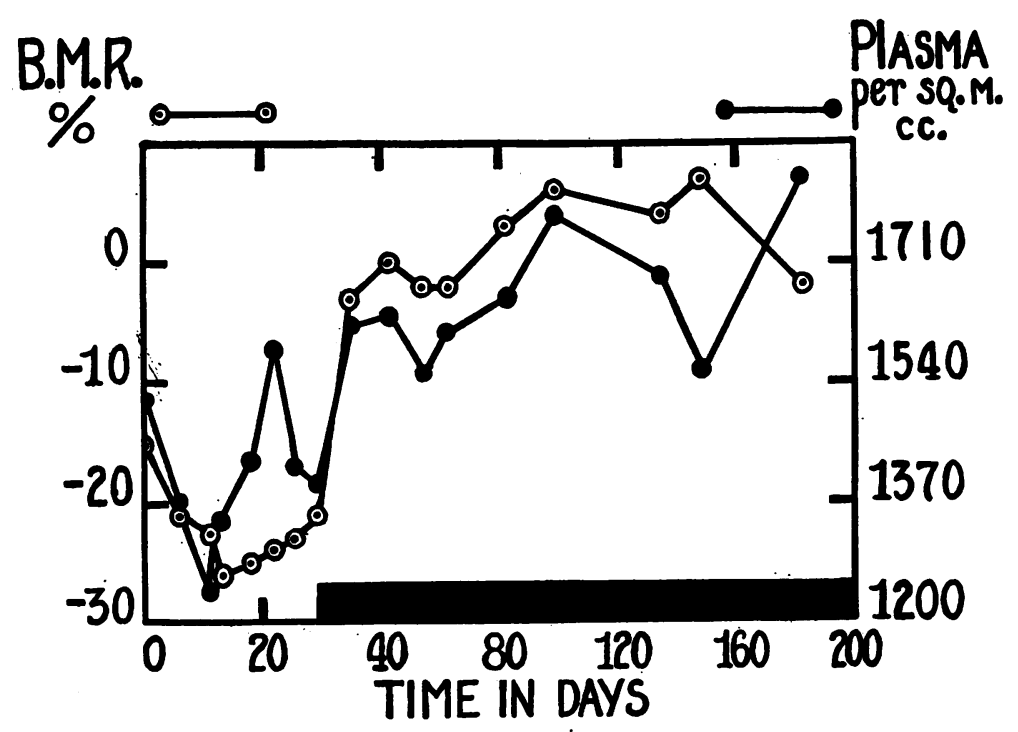

Fig. 3. CASE of MyXedema No. 8

These curves likewise show parallelism between B.M.R. and plasma per square meter. Thyroid extract administration omitted about three weeks before the first recorded observation.

be observed that there are differences in the reactions of different patients. These are related neither to the differences in basal metabolic rate nor to those in maintenance dosage of thyroid extract. They are probably manifestations of individual variation and represent fundamental differences in human constitution. They may be likened to the marked variations in the extent of anhydremia produced by the same dose of insulin in different rabbits of approximately the 
same weight (Drabkin and Edwards (23)), to the marked variation in the severity of myxedematous symptoms in different patients with essentially the same reduction in basal metabolic rate and to the marked variation in the amount of thyroid substance required to main-

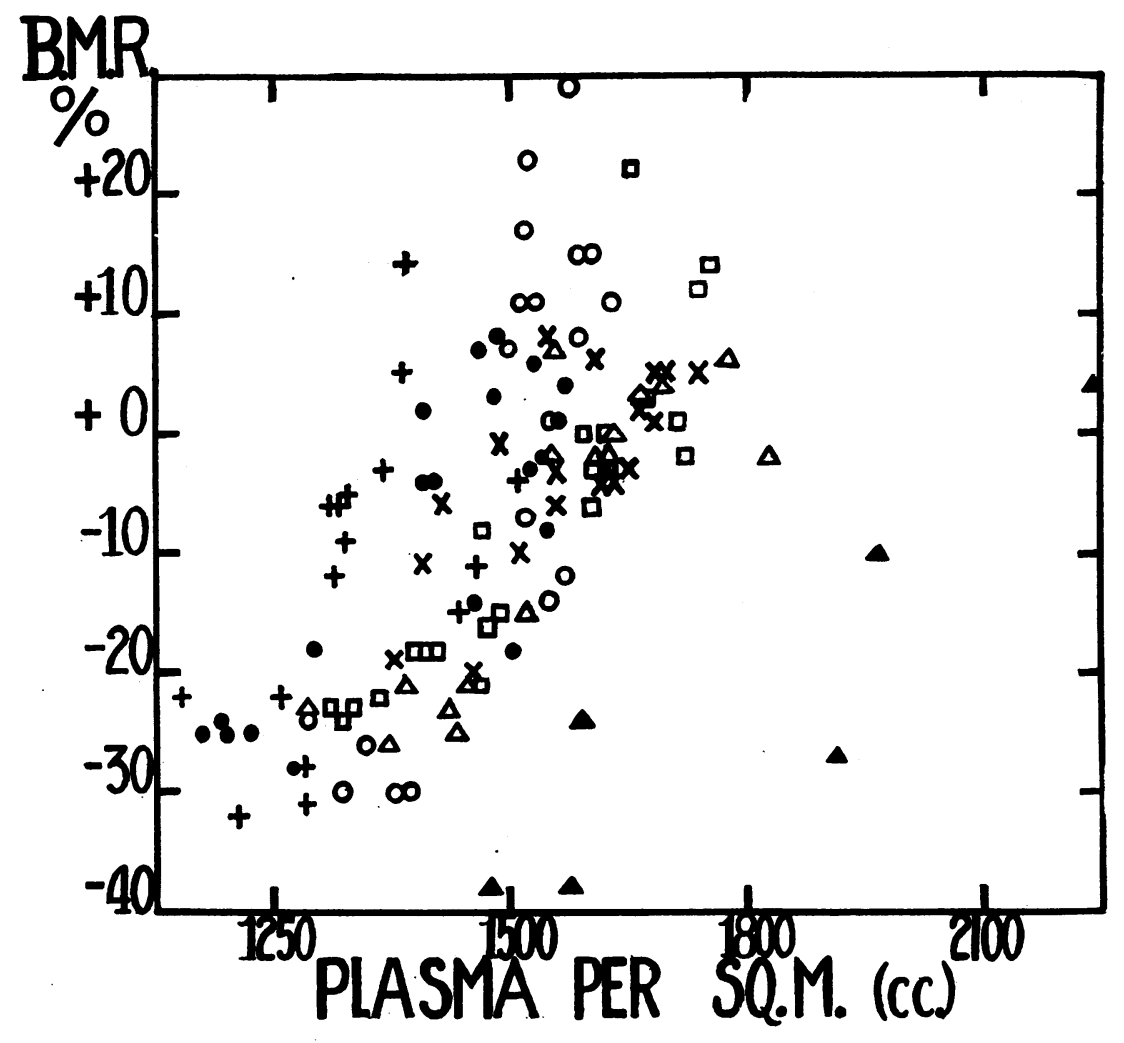

Fig. 4. B.M.R. vs. Plasma per Square Meter. All Cases

Observations on case 3 shown by black triangles.

Observations on case 4 shown by dots.

Observations on case 5 shown by squares.

Observations on case 6 shown by circles.

Observations on case 7 shown by crosses.

Observations on case 8 shown by white triangles.

Observations on case 9 shown by pluses. 
tain the normal basal metabolic level in patients with myxedema who show about the same reduction in basal metabolism. ${ }^{4}$

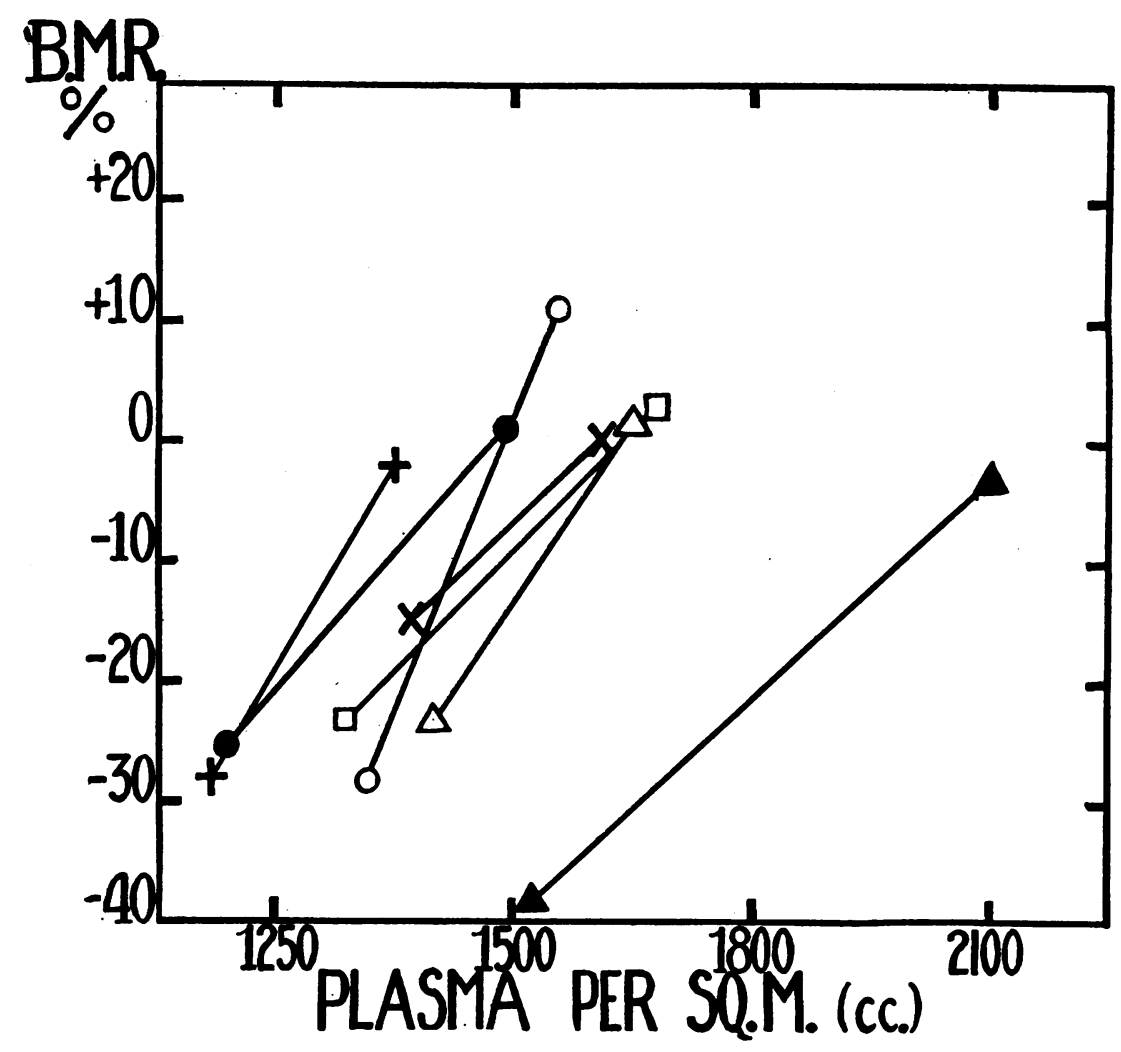

Fig. 5. The Relation of B.M.R. to Plasma Per Square Meter is Shown in ALL THE CASES

For each case represented in figure 4 , a mark has been plotted for the average B.M.R.-plasma per square meter point when free from, and another during, thyroid extract administration; the two are connected by a straight line.

${ }^{4}$ It is not implied that basal metabolism and plasma volume always increase together. There are no doubt different types of accelerated and diminished cellular activity. For example, the oxygen consumption is increased in fever, but evidence thus far collected suggests that the blood is concentrated. 
VII. THE RELATION BETWEEN THE DOSE OF THYROID EXTRACT ${ }^{5}$ AND THE DEGREE OF PLASMA INCREASE IN THE SAME INDIVIDUAL

It is striking that once the basal metabolism has been restored to its normal level, increases in the dose of thyroid extract up to three and

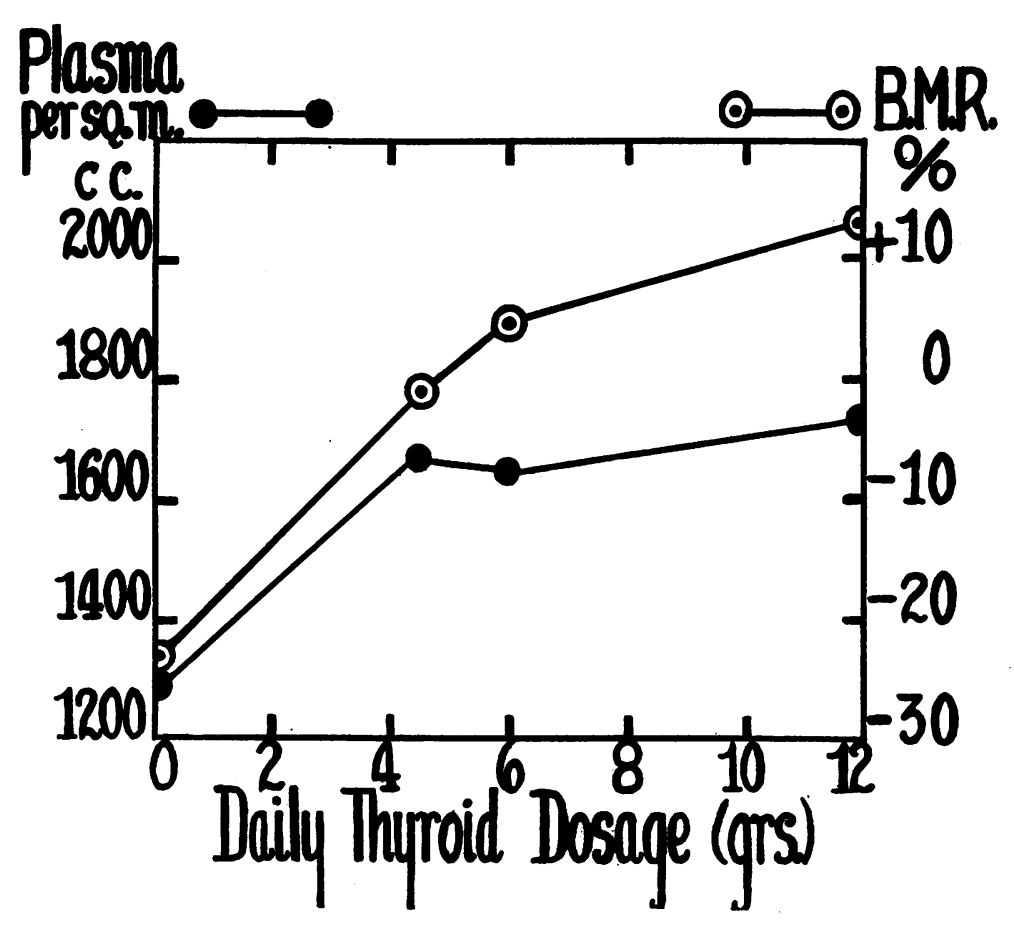

Fig. 6. Case of Myxedema No. 5

These curves show the effect on B.M.R. and plasma volume of increasing the dose of thyroid extract beyond the maintenance dose. Each point represents the average of at least two observations.

${ }^{5}$ Burroughs Wellcome and Company's thyroid extract was used throughout this work, except for the first four weeks in case 8, during which Armour's 1 grain tablets were used. In the last six patients Burroughs Wellcome and Company's thyroid preparation was used in $1 \frac{1}{2}$ grain tablet strength only. In cases 8 and 9 oral thyroxin in large doses was used without effect on basal metabolic rate or plasma volume, whereas thyroid extract subsequently produced a prompt and sustained increase in both. Twenty milligrams of thyroxin were injected intravenously in case 9, while she was myxedematous. A well marked increase in basal metakolic rate and plasma volume occurred, the data being recorded in table 11. 
four times the maintenance dose produce only slightly greater increases in plasma volume and basal metabolism than the maintenance dose (figs. 6 and 7). One observes the abrupt change in direction of the two lines when the dose is pushed beyond the maintenance dose.

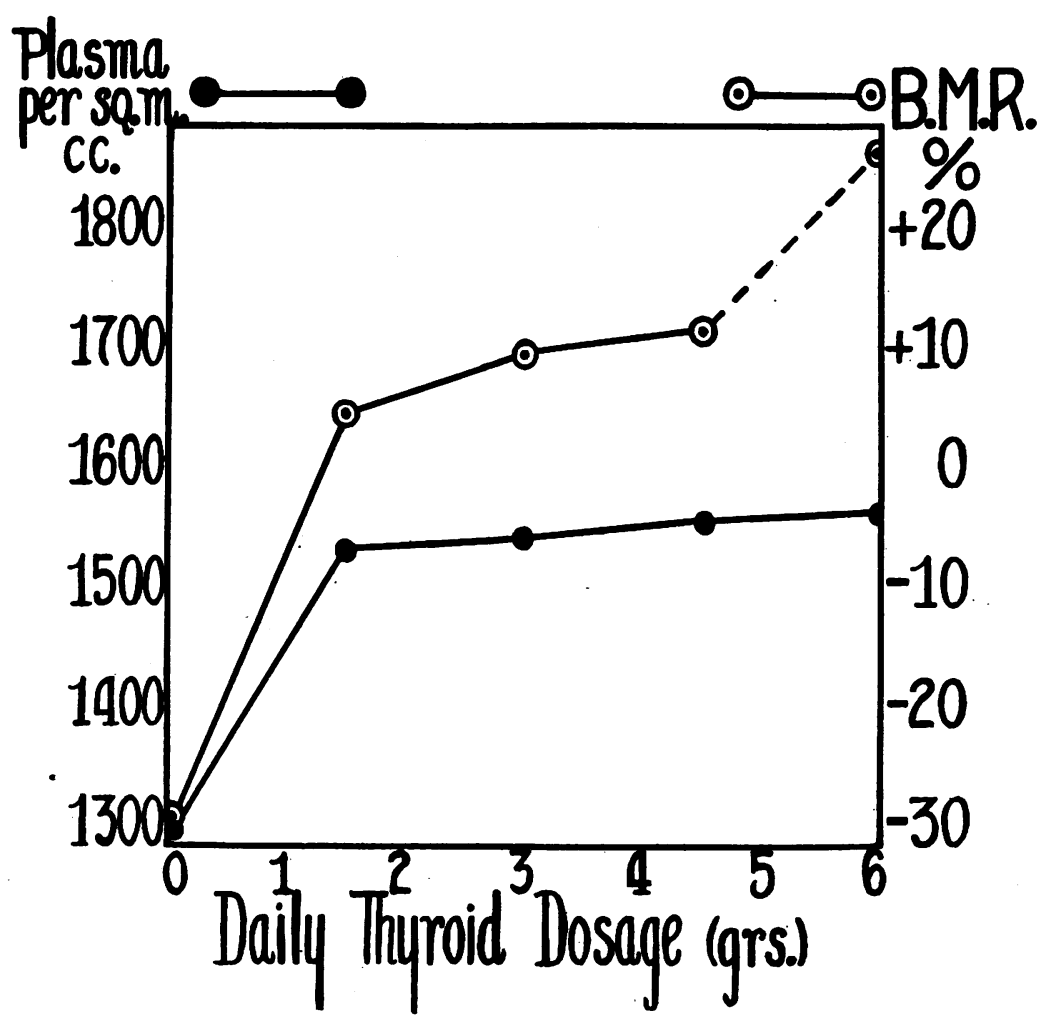

Fig. 7. Case of Myxedema No. 6

These curves likewise show the effect on B.M.R. and plasma volume of increasing dose of thyroid extract beyond the maintenance dose. The B.M.R. on 6 grains daily represents only one observation and is probably high inasmuch as one of the three B.M.R. observations on $4 \frac{1}{2}$ grains daily was +23 per cent.

Yet, in spite of little change in plasma volume or basal metabolism, these patients would often complain of precordial pain, palpitation epigastric cramps and dysmenorrhea. One woman (case 7) whose 
auricles were fibrillating and whose maintenance requirement was $7 \frac{1}{2}$ grains daily had an attack of unconsciousness (probably StokesAdams) ${ }^{\circ}$ on two occasions when the dose was increased to 12 grains daily. She had had none before and has had none since.

One may compare the difficulty experienced in raising basal metabolism and increasing plasma volume once the basal metabolism is normal with the difficulty encountered in raising both in a normal individual by giving thyroid extract (table 12). This individual probably belonged to the so-called "low rate" group of patients. She showed only a slight increase in basal metabolism and a suggestive slight increase in plasma volume on taking $4 \frac{1}{2}$ to 6 grains of thyroid extract daily. Yet she had precordial pain, palpitation, epigastric pain and severe dysmenorrhea, all of which disappeared when the administration was stopped.

Data were collected also from a postoperative exophthalmic goitre patient who may be regarded as approximately normal (table 13). The data begin to be recorded about four months after a subtotal thyroidectomy, that is to say, after the weight had become stationary. Iodine (Lugol's solution) was first given for about $5 \frac{1}{2}$ weeks. The basal metabolism on iodine treatment dropped slightly to a stationary level around -5 per cent. Thyroid extract was then administered in slowly increasing doses over a period of about $2 \frac{1}{2}$ months. The patient was given $13 \frac{1}{2}$ grains daily for approximately one and onehalf months. There occurred a slight increase in basal metabolism (18 points) and possibly a slight increase in plasma volume (1560 cc per square meter to $1670 \mathrm{cc}$. per square meter). The patient experienced no toxic symptoms on $13 \frac{1}{2}$ grains of thyroid daily a dose sufficiently large to produce intoxication in most patients with myxedema. These last two patients illustrate what appears to be a matter of importance, namely, variations in the amount of thyroid extract re-

${ }^{6}$ It is of interest in this connection that Willius (48) recommends the use of small doses of thyroid extract (1 to 2 grains daily) in the treatment of the AdamsStokes syndrome and that Aub and Stern (49) report that the daily administration of 28 grains of Burroughs Wellcome and Company's.thyroid extract for several weeks produced no cardiac symptoms in a patient with complete heart block, in spite of an increase in basal metabolism to +47 per cent. 


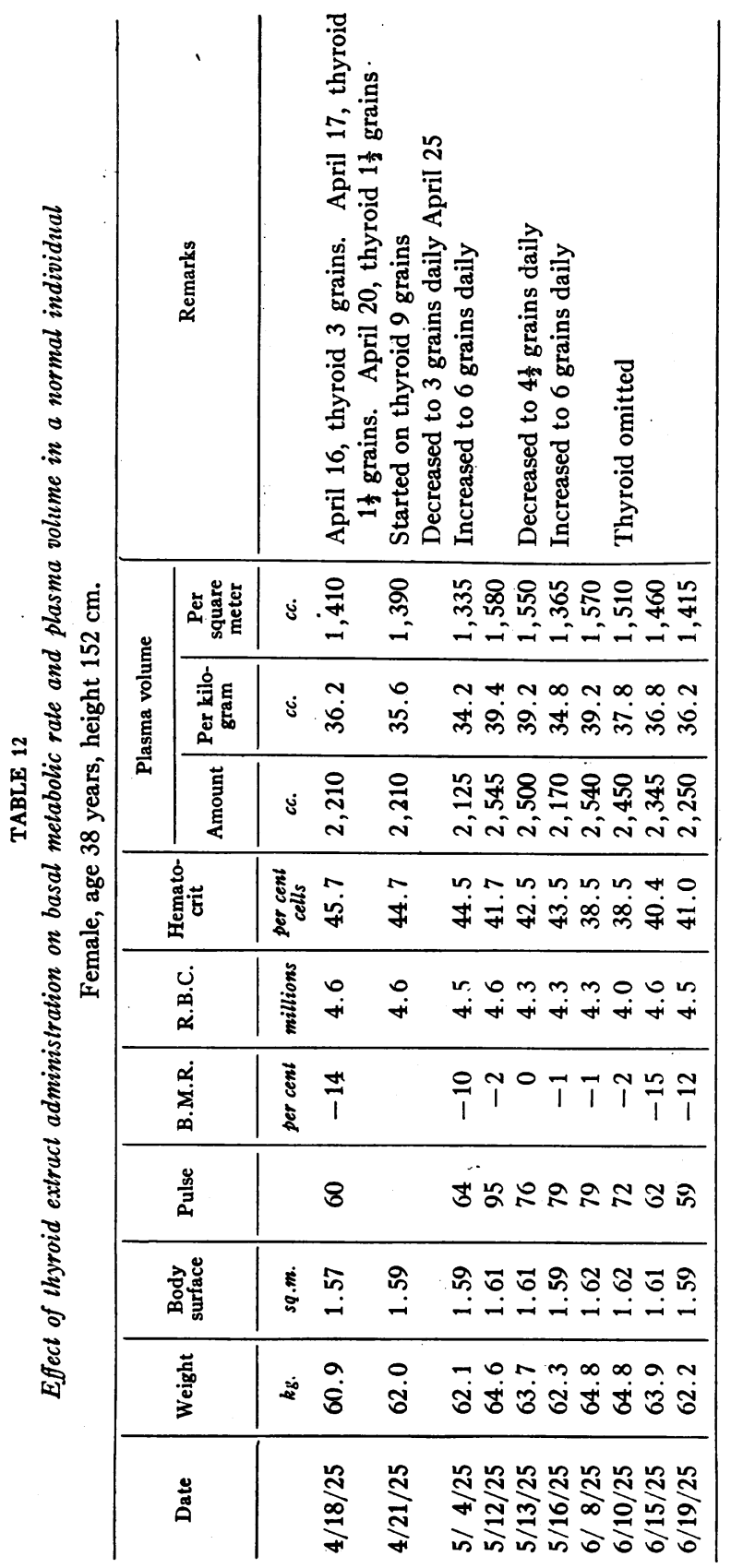




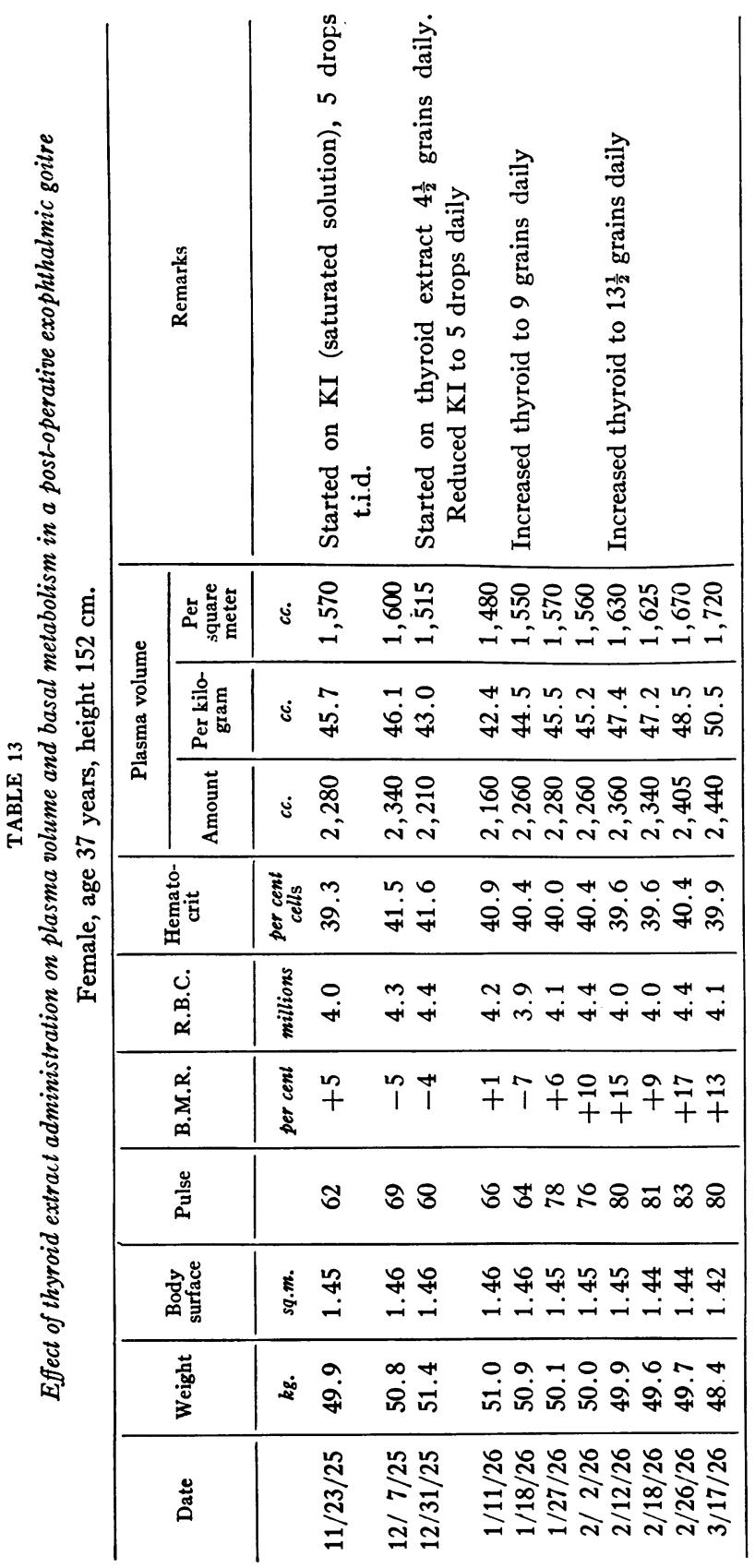


quired to produce intoxication in different normal individuals. ${ }^{7}$ It is significant that when one plots the basal metabolism and plasma per square meter against the dose of thyroid extract for the patient after thyroid operation (table 13, fig. 8) one gets the same type of curves as is seen in figures 6 and 7 after the maintenance dose of thyroid is reached.

Other cases could be cited. These are sufficient, however, to illustrate that once a patient with myxedema has been given sufficient

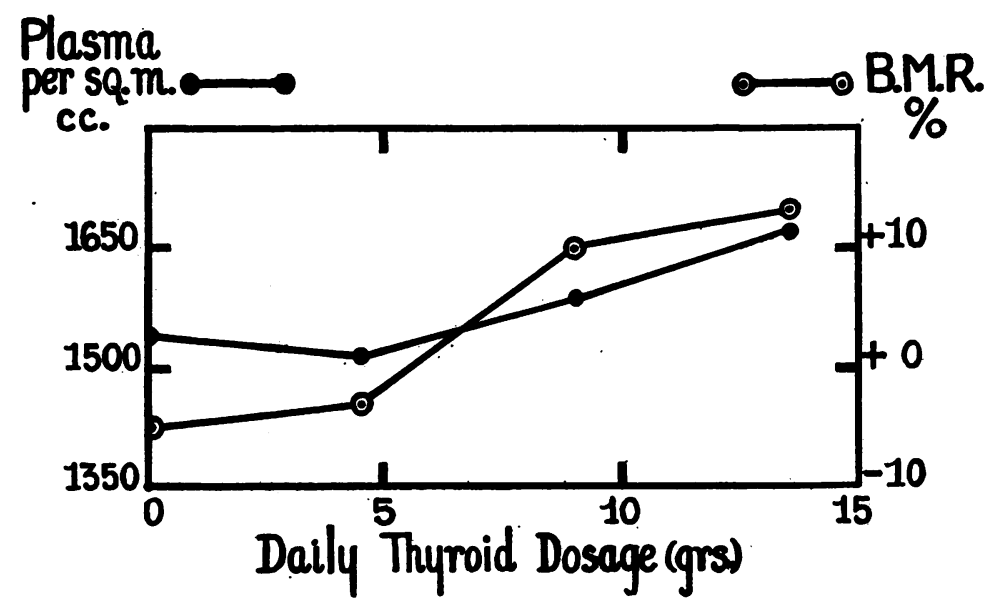

FIG. 8

These Curves present the record of a case of exophthalmic goitre during a period of thyroid extract therapy beginning four months after a subtotal thyroidectomy (Table 13).

Note that the abrupt initial rise (maintenance dose) seen in figures 6 and 7 is lacking.

thyroid to maintain a normal basal metabolism and plasma volume, one is dealing with an essentially normal individual. When the dose of thyroid extract is further increased up to two or four times the maintenance dose, the increases in basal metabolism and plasma vol-

${ }^{7}$ It is realized, of course, that post operative patients with exophthalmic goitres, although not grossly myxedematous, may possibly require more thyroid extract before they become toxic than normal individuals. This may account in some measure for the difference, but probably not completely. 
ume are proportionately much smaller than those produced by the maintenance dose and are of the same magnitude as the changes produced in both by giving thyroid extract to a normal individual. This phenomenon is probably fundamental and seems to be the result of calling into play some defense mechanism, some one of the body's factors of safety to deal with excess.

\section{CHANGES IN TOTAL BLOOD VOLUME.}

In untreated cases of myxedema a well marked secondary anemia with a hemoglobin of about 60 per cent and a red blood cell count of between $3,000,000$ and $4,000,000$ is the rule rather than the exception and has been emphasized by numerous observers including Minot (24), Emery (25), and recently McKunde (26). She found a decrease in hematocrit values in experimental myxedema in rabbits from 30 to 31 per cent to 23 to 24 per cent, and a reduction in hemoglobin of 30 to 40 per cent. This reduction in hematocrit value does not represent the total reduction in volume of circulating cells because there was probably also a reduction in plasma volume. Even if the plasma volume is concentrated only 15 per cent as the result of thyroidectomy, then an hematocrit reading of 23 really is too high and represents one of 19.5 based on the original quantity of plasma. If the original hematocrit value were 30 this would represent a reduction in volume of circulating cells of over one-third and in total blood volume of over one-fifth, reductions which may fairly be assumed.

The reduction in red count and cell volume following the omission of thyroid extract administration is a slow one; the first response is in fact an increase due to plasma reduction. It is manifestly unfair to keep patients with myxedema off the administration of thyroid extract long enough to allow the red count and cell volume to be lowered. There is evidence, however, in the data presented which allows one to draw justifiable conclusions about changes in total blood volume.

For example, consider again case 1 (table 3). Her hematocrit reading just after starting the administration of thyroid extract but before the drug had had any effect, averaged 26.5, with an average red count of 3.1 millions. Thyroid extract was administered for about 
seven months and was then omitted for about six weeks (May 14, 1924 , to June 27, 1924). During this period the average plasma volume was $2615 \mathrm{cc}$. Observations made from July 3, 1924, to September 29, 1924, while taking thyroid extract show an average hematocrit value of 35.6, an average red count of 3.9 millions and an average blood volume of $4600 \mathrm{cc}$. Let is be assumed that the plasma volume in the myxedematous state before she received thyroid extract was the same as it was when its administration was omitted, namely, $2615 \mathrm{cc}$. This, with an hematocrit value of 26.5 gives a total blood volume of $3560 \mathrm{cc}$., or $1140 \mathrm{cc}$. less than the total volume after she had reached an equilibrium on thyroid extract treatment. This seems a conservative estimate, since the first two plasma volume observations of 1850 and $2350 \mathrm{cc}$. (although questionable, as stated on page 497) would give still lower total blood volumes for her original myxedematous condition.

Case 2 (table 4) presents a second example. It was possible to withhold thyroid extract from this patient for a period of over three months (January 7, 1924 to April 16, 1924). It will be observed that although the hematocrit reading increased at first, towards the end of the period it decreased slightly. Then after medication began again (April 16, 1924) there occurred following a further decrease, an increase which set in about one month later and gradually became more marked during the following four months. If the average of the last three total blood volumes (March 22, 1924, to April 14, 1924) when he was not taking thyroid extract be compared with the average of the last five (August 14, 1924, to September 11, 1924) during its administration, an increase in total blood volume of $1245 \mathrm{cc}$. will be observed. The data suggest that the original cell volume was less than when treatment was subsequently omitted, considering that the red count on admission averaged between 2.0 and 3.0 millions as compared with 4.0 millions during the untreated period beginning January 7, 1924. The change of $1245 \mathrm{cc}$. in total volume is one actually observed and is probably less than the change that would have been recorded had observations been made before thyroid therapy was begun.

Case 6 had been without thyroid extract for two months when last admitted to the hospital. The total volume (5 observations made 
from July 29,1925 , to August 7,1925$)$ averaged $4270 \mathrm{cc}$. before the administration of thyroid extract was started August 7, 1925, and the 5 last observations, made in the fourth month after starting treatment averaged $4895 \mathrm{cc}$. an increase of over $600 \mathrm{cc}$.

From such data, together with experimental observations in animals following thyroidectomy, it appears that increases in total blood volume of one-fourth over the myxedematous level (i.e., 800 to $1000 \mathrm{cc}$. of whole blood in human beings) are not uncommon.

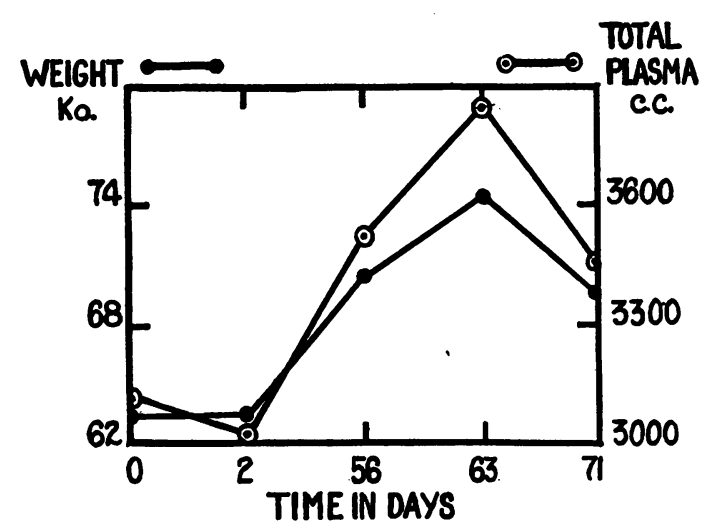

Fig. 9. Cardiac Edema

These curves show increase and decrease in total plasma volume with increase and decrease in edema (represented by weight curve).

\section{A COMPARISON OF MYXEDEMA AND CARDIAC EDEMA}

Myxedema and the edema of heart disease represent two totaliy different types of edema and, by comparing them, some light is thrown on the nature of both. In cardiac edema, the excess tissue fluid is chiefly intercellular and the skin pits on pressure. In myxedema the excess tissue fluid is chiefly intracellular and the skin does not pit on pressure. Cardiac edema may be explained on the basis of an increased capillary filtration pressure due to venous congestion (that is to say, this may be the underlying cause of all blood and tissue changes). Indeed, when one stands at the position of attention for as long as an hour, the cardiac output decreases, the venous pressure rises and a measurable increase occurs in the diameter of the calf (Field 
and Bock (27)). Bolton produced marked edema by reducing the lumen of the inferior vena cava to one-third in cats. Myxedema, on the other hand, probably has a much more complex mechanism as a result of changed osmotic relations between plasma and tissue cells. This subject is discussed later in greater detail.

In cardiac edema as the weight increases the total plasma increases, whereas in myxedema as the weight increases the total plasma decreases. This is illustrated in figures 9 and 10, where the weight curves and total plasma volumes are plotted for a case of cardiac edema and case 5 with myxedema. The data for figure 9 were collected from

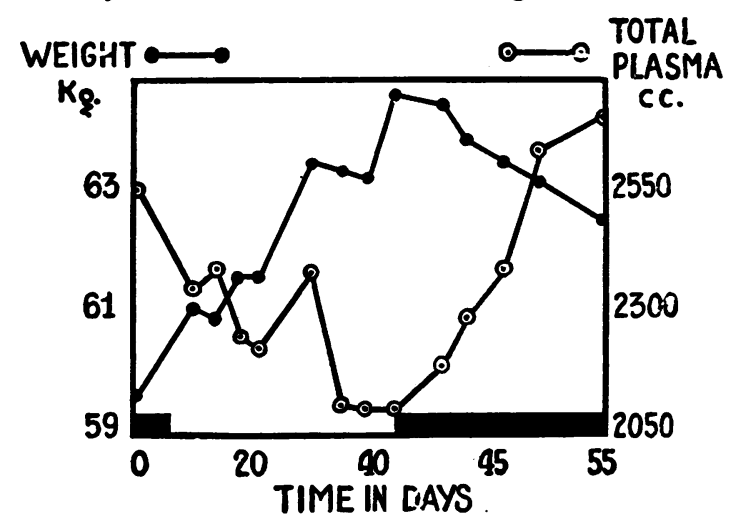

Fig. 10. Case of Myxedema No. 5

These curves show decrease in plasma volume with increase in weight and increase in plasma volume with decrease in weight in contrast to those in cardiac edema (fig. 9).

a case of chronic myocarditis which I was fortunate enough to observe while fully compensated, during the progress of edema and as edema was subsiding. ${ }^{8}$

Another point of interest in cardiac edema is that the osmotic

${ }^{8}$ There is considerable evidence in the literature to support my findings in cardiac edema. As early as 1884 Oertel (29) taught that in cardiac edema, hydremic plethora was present. Stintzing and Gumprecht (30) found hydremia not only during the height of dropsy, but also at the onset. Askanazy (31) concluded from his observations that the blood serum was always diluted, dilution depending upon the extent of the dropsy. Bolton (32) found a well marked increase in blood volume in animals in experimentally produced "dropsy." 
pressure of the serum as referred to protein is low (Gavaerts (28)) whereas the data in myxedema thus far collected suggest that the serum protein is high. Inasmuch as hunger edema is also characterized by low serum protein and massive pitting edema, Oberndorfer's (1) finding of a markedly diminished weight of the thyroid gland in this condition appears to be of no consequence from the standpoint of etiology of the edema.

X. THE EFFECT OF THYROID ADMINISTRATION ON THE PLASMA VOLUME IN CRETINS

A few observations on three cretins have been collected. Two of these (aged 4 and 5 years) showed practically no change after taking fairly large doses of thyroid extract for two to four weeks. The third case (aged 7 years) showed a 14 per cent increase, in total plasma after receiving 3 to 4 grains daily for three weeks. There are, however, not enough data to draw conclusions from. These findings are interesting in view of those of Hammett (50) that thyroidectomy in male rats 75 days of age produced much less increase in refractive index and much less reduction in water percentage of serum than it did in sexually mature male rats 100 days of age.

Young rabbits when thyroidectomized show reductions in hematocrit values which are less marked than those shown by mature rabbits (McKunde). An increase in hematocrit readings on giving thyroid extract has been observed in human cretinism (Talbot (33)).

XI. THE RATE OF DISAPPEARANCE OF INTRADERMALLY INJECTED SALT SOLUTION IN MYXEDEMA BEFORE AND AFTER THYROID EXTRACT ADMINISTRATION.

The Aldrich-McClure intradermal skin test $(34,35)$ was used. Sodium chloride solution $(0.2 \mathrm{cc}$. of an 0.8 per cent $)$ was injected intradermally in two places about $2 \mathrm{~cm}$. apart on the flexor surface of each forearm a little below the bend of the elbow. The time at which an elevation ceased to be palpable on gently rubbing the finger over the point of injection was taken as the end point of the period of absorption. I do not consider the test of much value. Leakage, no matter how careful the technique, causes variation in the amount of fluid 
injected. Differences in the depth of injection are unavoidable. Irritation of a sensitive skin often masks the end point. I have, however, several observations in four cases under and without the influence of thyroid extract and I present the averages in each case. They consistently show a more prolonged disappearance time before or in the interval of thyroid omission than during the period of administration.

\begin{tabular}{c|c|c}
\hline Case number & Average without thyroid extract & Average on thyroid extract \\
\cline { 2 - 3 } 4 & minutes & minutes \\
5 & 67 & 40 \\
6 & 71 & 56 \\
9 & 122 & 95 \\
& 63 & 44 \\
\hline
\end{tabular}

It is interesting to notice that in all other types of edema Aldrich and McClure found the disappearance time markedly diminished. The wheals usually disappeared in 7 minutes or less over markedly edematous areas. Although the time was usually greater in nonedematous than in edematous areas of the same patient, the time in non-edematous areas of edematous patients was usually much less than the normal of $\mathbf{5 0}$ or $\mathbf{5 0}$ plus minutes. In a case of nephrosis at this hospital it was observed that in the legs where edema was marked the wheals disappeared in 1 to 2 minutes whereas in the arms where no pitting edema was present the wheals took 12 to 14 minutes to disappear. Obviously this rapid disappearance in edema cannot be due to capillary absorption for the following reasons:

1. The blood has a low osmotic pressure (as referred to protein) and can not properly absorb fluid from the tissues. Yet the wheal often disappears at 40 to 50 times the normal rate.

2. Differences in the chemical composition of blood sufficient to account for differences in disappearance time of 6 to 14 times are not known to exist.

3. The disappearance time increases as edema subsides, a relation just the opposite of what one would expect if disappearance were due chiefly to absorption by the blood.

One could account for the differences in disappearance time in myxedema before and after the administration of thyroid extract on the basis of changes in the rate of blood flow, assuming that the dis- 
appearance in this case were chiefly the result of absorption by the blood. Until we know more precisely, however, what the mechanism of disappearance is, it is useless to say more on the subject. The results illustrate one more difference, nevertheless, between myxedema and all other types of edema. Pilcher (36) on injecting codein intradermally noticed that the injection wheals disappeared more rapidly than normal in a case of myxedema and in one cretin, as well as in other types of edema. It is important in such instances, however, not to confuse irritation with diffusion and absorption phenomena.

\section{DISCUSSION}

Magnus-Levy (37) showed that there was accumulation of albumen in the tissues in myxedema and thought that some of the increase was intercellular. Eppinger (11) assumed that this phenomenon was the cause of edema in myxedema by virtue of the affinity of albumen for water and salt. He inclined to the view, that in edema of this type intercellular albumen was a more important constituent than intracellular albumen and based this conclusion on the fact that when isotonic salt solution was injected subcutaneously in myxedematous dogs, protein became mixed with it whereas this did not occur in normal dogs. In his opinion protein admixture was responsible for slow absorption. Eppinger believed in fact that increased tissue albumen accounted for all types of edema. Boothby et al. (51) confirmed the observation of Magnus-Levy and showed that the nitrogen-water ratio of the weight lost by one normal and by each of two myxedematous individuals as a result of intravenous thyroxin administration was $1.9,2.0$ and 1.9 per cent respectively. These authors, therefore, concluded that the edema of myxedema "corresponds apparently to an increase in the reserve or deposit protein" and "is an albuminous colloid fluid with a nitrogen-water ratio higher than the average of 1.1 per cent for human blood serum and identical with that of egg white which contains approximately 2 per cent nitrogen, and definitely less than that of muscle which contains over 3 per cent." They emphasized the fact that on the contrary the nitrogen content of the edema of cardiac or renal origin is only 0.05 to 0.001 per cent, a negligible amount. 
In comparing myxedema with cardiac edema it was suggested that the increased tissue fluid in myxedema was probably for the most part intracellular. Tatum (38) has shown that in experimental cretinism in rabbits, while there is a varying amount of intercellular serous deposit, the greater changes are in the cells. He demonstrated that there were hydrophic changes in cells of the heart, liver, kidney, smooth and striated muscle. These experiments then give evidence to the effect that there may be increased water content of tissue cells.

That the water content of the tissues is increased in myxedema is a generally accepted fact. Recently McKunde has reported that the water content of dried fat-free tissue in thyroidectomized rabbits is higher than normal and that they lose weight and water when fed with thyroid extract. Hildebrandt has shown that the intravenous injection of thyroxin in rabbits causes not only a loss of water from the tissues but also of salt. It is, moreover, generally admitted that the secretion of the thyroid gland stimulates sodium chloride metabolism.

In myxedema there are then two phases in close association; first a reduction in the total quantity of circulating plasma, and second an increase in water protein, and salt in the tissues. It is my opinion that both these phenomena are merely by-products of the fundamental change which thyroid insufficiency produces in the activity and chemical composition of tissue cells.

It is interesting in this connection to refer to the work of Barbour and Hamilton (39), (40), (41) who have demonstrated that cold produces blood concentration, and heat blood dilution, and that in cold anhydremia there is an increase in the water content.of skin and muscle. They have not demonstrated whether this increased tissue water is intra- or extracellular. The idea is suggested, however, that cold and thyroid insufficiency may produce similar types of slowed cellular metabolism and that a by-product of both is probably an increased osmotic pressure of tissue cells.

Ellinger (42) believes that the influence of thyroid extract on the viscosity of blood serum is independent of the albumen content of the latter, and that in this respect its action is similar to that of caffeine and other diuretics.

Loeb (43) reports that Embden and his associates found that thyroid extract, when added to certain substances increases the rapidity 
with which the latter pass in vitro through a membrane of frog's skin. He also reports that "Recent experiments in Asher's laboratory have shown that under the influence of thyroid, methylene blue passes more rapidly from the body fluids into glandular structures in the membrane nictitans of the frog. Thyroid extract would thus appear to have an effect opposite to that of calcium chloride and adrenalin." In view of such reports one must admit that altered permeability of cell membranes may play a rôle in the effect of thyroid extract on fluid distribution in myxedema, but it would appear to be a minor rôle and to be explicable on the theory that cell membranes share in the general myxedematous condition.

Means (17) has well remarked that "However obscure the function of the endocrine glands may be, we can agree, I think, that they are all concerned in one way or another, direct or indirect, with metabolism. . . . . If the secretions of endocrine glands influence cell activity, they must also influence the supply of the medium upon which such activity depends." We know that insulin produces a well marked anhydremia, that adrenalin causes some anhydremia and that pituitrin has a marked effect on water elimination. Krogh (44) indeed thinks that it decreases capillary permeability.

Means also referred to the observation of Bock and Field (45) that in myxedema the administration of thyroid extract markedly increased the minute volume of the heart, initially very low. He referred to the reduction in the volume of blood and in cardiac output as manifestations of the variation in the supply of circulating medium with the demand. Daly (46) has shown that mere increases in the volume of blood, other things being equal, increase the cardiac output. As already stated, I have observed an increase of $1245 \mathrm{cc}$. in total circulating blood in one patient and have calculated that it must have been about this great in another. The value of such increases from the standpoint of hemodynamics is obvious. It is indeed, quite striking that the secretion of the thyroid gland with its marked influence on oxygen consumption should produce such marked changes in the carriers of oxygen and carbon dioxide. As Barcroft (47) has so well put it "The blood volume should be regarded not as aliquot part of the body weight but.as a physiological variable which is adjusted to the work required of it. . . . ." 
In brief, the reduction in plasma volume in myxedema is associated with an accumulation of albumen, water and salt in the tissues. It is a debatable point as to how much of this increase is intercellular and how much intracellular. Eppinger's finding of a protein admixture in subcutaneously injected isotonic salt solution in myxedematous dogs, suggests that a considerable part of the increase may be intercellular. On the contrary the contrast between myxedema and cardiac edema, together with Tatum's finding of an hydropic condition of various tissue cells in thyroidectomized rabbits, indicate that the larger part of the increase may be intracellular. A factor in these changes may be diminished permeability of cell membranes. The fundamental cause of all the blood changes, however, would appear to be a decrease in the rate of metabolism of tissue cells, with a diminution in the demand for oxygen and carbon dioxide transport. The decreased quantity of circulating medium and the reduction in minute volume of the heart seem to be adaptations of the circulatory system to this diminished demand. I have suggested that the slowed cellular metabolism may increase cellular osmotic pressure, but the various steps in the process by means of which water is slowly withdrawn from plasma and stored up in the tissues, are yet to be worked out.

\section{SUMMARY AND CONCLUSIONS}

In nine patients with myxedema the total plasma volume increased on the average 22.9 per cent, the plasma per kilogram 28.5 per cent, and the plasma per square meter 25.2 per cent, when given thyroid extract.

From observed and calculated increases in total blood volume, it is estimated that the administration of thyroid extract in myxedema not infrequently produces total blood volume increases of 25 per cent.

The plasma decrease on omission of thyroid extract and the increase on administering it, occur much more rapidly than the same changes in the volume of cells. Plasma reduction is usually well marked within ten days after omitting the drug.

A parallelism exists in myxedema between basal metabolism and plasma volume.

Once the basal metabolism has been restored to normal, further increases in the dose of thyroid extract up to four times the mainte- 
nance dose produce proportionately much smaller increases in plasma volume and basal metabolism than the maintenance dose.

The plasma volume changes in myxedema are contrasted with those in cardiac edema in which plasma volume increases with increasing edema. Other differences in the two are noted.

In particular I wish to thank Dr. James Howard Means for his interest in this work and for help in the preparation of the manuscript. I also wish to thank Dr. Francis W. Peabody for giving me a place to work while I was a house officer.

\section{BIBLIOGRAPHY}

1. Leichtenstern, O.: (Quoted from Oberndorfer.) Münch. med. Wchnschr., 1919, lxvi, 196. Aerztlicher Verein München Sitzung vom 15 Mai 1918.

2. Gardella, E.: Arch di fisiol., 1910, viii, 409. Le costanti fisico-chimiche del siero di sangue di cano dopo l'ablazione dell'apparato tiropartiroideo.

3. Paladino, R.: Biochem. Ztschr., 1912, xlii, 302. Veränderung der physikalisch-chemischen Eigenschaften des Blutserums und des Harnes von Hunden nach Schildrüsenexstirpation.

4. Fano, G., and Rossi, G.: Arch. di fisiol., 1904-5, ii, 589. Sulla viscosità del siero sanguigno nelle lesioni sperimentali dell'apparecchio tiro-paratiroideo.

5. Kottmann, K., and Lidsky, A.: Ztschr. f. klin. Med., 1910, lxxi, 362. Ueber den Fibringehalt des Blutes inZusammenhang mit der Schilddrüsenfunktion. Gleichzeitig ein Beitrag zum Fibringehalt des normalen menschlichen Blutes.

6. Deutsch, G.: Deutsches Arch. f. klin. Med., 1920, cxxxiv, 342. Serumkonzentration und Viskosität des Blutes beim Myxödem und ihre Beeinflussung durch Thyreoidin.

7. Neuschlosz, S. M.: Klin. Wchnschr., 1924, iii, 1013. Über die Beziehungen der spezifischen Viskosität des Blutserums zur Höhe des Grundumsatzes bei Funktionsstörungen der Schilddrüse.

8. Hammett, F. S.: Amer. Jour. Physiol., 1923, lxiv, 467. Studies of the Thyroid Apparatus. X. The Refractive Index and Water Content of the Blood Serum of Male and Female Albino Rats Thyro-Parathyroidectomized and Parathyroidectomized at $\mathbf{1 0 0}$ Days of Age

9. Petersen, W., Jobling, J. W., and Eggstein, A. A.: Jour. Exp. Med., 1916, xxiii, 499. Serum Changes Following Thyroparathyroidectomy.

10. Etienne, G., Richard, G., and Roesch, J.: Compt. rend. Soc. de biol., 1925, xcii, 1095, Le métabolisme azoté au cours de l'insuffisance thyroidienne.

11. Eppinger, H.: Zur Pathologie und Therapie des menschlichen Oedems. Berlin, 1917.

12. Danzer, C. S.: Proc. Soc. Exp. Biol. and Med., 1923-1924, xxi, 298. The Influence of Thyroid Substances on the Absorption of Pleural Effusions. 
13. Loeb, Leo: Medicine, 1923, ii, 280. Edema.

14. Wilhelmj, C. M., and Fleisher, M. S.: Jour. Exp. Med., 1926, xliii, 179. The Relation of the Thyroid Gland to the Surface Tension of the Blood Plasma. I. The Effect of Thyroidectomy.

15. Wilhelmj, C. M., and Fleisher, M. S.: Jour. Exp. Med., 1926, xliii, 195. The Relation of the Thyroid Gland to the Surface Tension of the Blood Plasma. II. The Effect of the Administration of Thyroid Extract and Thyroxin.

16. Hildebrandt, F.: Klin. Wchnschr., 1924, iii, 279. Utber den Einfluss von Thyroxin auf die Diurese.

17. Means, J. H.: Endocrinology, 1925, ix, 192. Circulatory Disturbances in Diseases of the Glands of Internal Secretion.

18. Keith, N. M., Rowntree, L. G., and Geraghty, J. T.: Arch. Int. Med., 1915, xvi, 547. A Method for the Determination of Plasma and Blood Volume.

19. Hooper, C. W., Smith, H. P., Belt, A. E.; and Whipple, G. H.: Amer. Jour. Physiol., 1920, li, 205. Blood Volume Studies. I. Experimental Control of a Dye Blood Volume Method.

20. Lamson, P. D., and Rosenthal, S. M.: Amer. Jour. Physiol., 1922-1923, lxiii, 358. The Inadequacy of our Present Blood Volume Methods.

21. Lamson, P. K., and Nagayama, T.: Jour. Pharm. and Exper. Therap., 1920, xv, 331. Blood Volume and Blood Volume Methods.

22. Plummer, H. S., and Boothby, W. M.: Amer. Jour. Physiol., 1921, lv, 295. Specific Dynamic Action of Thyroxin.

23. Drabkin, D. L., and Edwards, D. J.: Amer. Jour. Physiol., 1924, lxx, 273. The Production of Anhydremia with Insulin.

24. Minot, G. R.: M. Clinics N. America, Boston, 1921, iv, 1733. Two Curable Cases of Anemia.

25. Emery, E. S., Jr.: Amer. Jour. Med. Sc., 1923, n. s. clxv, 577. The Blood in Myxedema.

26. McKunde, M. M.: Amer. Jour. Physiol., 1926, lxxvi, 225. Blood Changes in Experimental Cretinism, Hyperthyroidism and Myxedema.

27. Field, H., Jr., and Bock, A. V.: Jour. Clin. Invest., 1925, ii, 67. Orthopnea and the Effect of Posture upon the Rate of Blood Flow.

28. Govaerts, P.: Bull. Acad. roy. de méd. de Belg., 1924, iv, 161. Recherches cliniques sur le rôle de la pression osmotique des protéines du sang dans la pathogénie des oedèmes et de l'hypertension artérielle.

29. Oertel: v. Ziemsen's Handbuch, 1894, Bd. iv. "Therapie der Kreislaufstörungen."

30. Stintzing and Gumprecht.: Deutsches. Arch. f. klin. Med., 1894, liii, 265. Wassergehalt und Trockensubstanz des Blutes beim gesunden und kranken Menschen: ein Beitrag zur Pathologie und Diagnose der Blutanomalien.

31. Askanazy, S.: Deutsches Arch. f. klin. Med., 1897, lix, 385. Ueber den Wassergehalt des Blutes und Blutserums bei Kreislaufstörungen, Nephritiden, Anämien und Fieber nebst Vorbemerkungen über die Untersuchungsmethoden und über den Befund unter physiologischen Verhältnissen. 
32. Bolton, C.: Jour. Path. and Bacteriol., 1915-1916, xx, 290. Further Observations on the Pathology of Cardiac Dropsy.

33. Talbot, F.: (Personal communication.)

34. McClure, W. B., and Aldrich, C. A.: Jour. Amer. Med. Ass., 1923, lxxxi, 293. Time Required for Disappearance of Intradermally Injected Salt Solution. Preliminary Report of Observations, with Special Reference to Cases of Edema.

35. Aldrich, C. A., and McClure, W. B.: Jour. Amer. Med. Ass., 1924, lxxxii, 1425. The Intradermal Salt Solution Test. II. Its Prognostic Value in "Nephritis" with Generalized Edema.

36. Pitcher, J. D.: Amer. Jour. Dis. Child., 1926, xxxi, 77. Wheal Formation in Infants and in Children: I. "In Edema, Cretinism," etc.

37. Magnus-Levy, A. : Ztschr. f. klin. Med., 1897, xxxiii, 269. Untersuchungen zur Schilddrüsenfrage; 1904, lii, 201. Ueber Myxödem.

38. Tatum, A. L.: Jour. Exp. Med., 1913, xvii, 636. Morphological Studies in Experimental Cretinism.

39. Barbour, H. G., Hamilton, W. F., Dawson, M. H., and Neuwirth, I.: Amer. Jour. Physiol., 1925, lxxii, 232. Mobilization of Salt and Water before Sweating, as Determined by the Specific Gravity: Solids Ratio of Blood and Serum.

40. Hamilton, W. F., and Barbour, H. G.: Amer. Jour. Physiol., 1925, lxxiii, 321. Heat Regulation and Water Exchange. VIII. The Fate of the Fluid Leaving the Blood in Cold Anhydremia.

41. Barbour, H. G., and Hamilton, W. F.: Amer. Jour. Physiol., 1925, lxxiii, 315. Heat Regulation and Water Exchange. VII. Evidence that Cold Anhydremia is Due to Loss of Fluid from the Blood Stream.

42. Ellinger, A.: Klin. Wchnschr., 1922, i, 249. Die Angriffspunkte der Diuretica.

43. Loeb, Leo: Medicine, 1923, ii, 281. Edema.

44. Krogh, A.: New Haven, 1924, 2nd edition, 156. Anatomy and Physiology of the Capillaries.

45. Bock, A. V., and Field, H., Jr.: (Unpublished data.)

46. Daly, I. De Burgh: Jour. Physiol., 1925, lx, 103. A Closed Circuit Heart Lung Preparation. I. Effect of Alterations in Blood Volume.

47. Barcroft, J.: Lancet, 1925, ccviii, 319. Recent Knowledge of the Spleen.

48. Willius, F. A.: Collected Papers of Mayo Clinic and Mayo Foundation, 1924, xvi, 541. Thyroid Preparations in the Treatment of the Adams-Stokes Syndrome.

49. Aub, J. C., and Stern, N. S.: Arch. Int. Med., 1918, xxi, 130. The Influence of Large Doses of Thyroid Extract on the Total Metabolism and Heart in a Case of Heart Block.

50. Hammett, F. S.: Jour. Metab. Research, 1924, iv, 65. The Water Content and Refractive Index of the Blood Serum of Albino Rats, Thyroparathyroidectomized and Parathyroidectomized at 75 Days of Age.

51. Boothby, W. M., Sandiford, I., Sandiford, K. and Slosse, J.: Tr. Assn. Amer. Phys., 1925, xl, 195. The Effect of Thyroxin on the Respiratory and Nitrogenous Metabolism of Normal and Myxedematous Subjects. 